\title{
Husband, sons and fertility gap: Evidence from India
}

\author{
Ankita Mishra ${ }^{1}$ and Jaai Parasnis ${ }^{2}$
}

\begin{abstract}
:
Fertility gap - the difference between a woman's ideal number of children and her actual number of children - is prevalent in both directions. We investigate the distribution of fertility gap in India and factors that lead to women exceeding or underachieving their ideal number of children. We find that son preference has a significant effect, contributing to negative as well as positive fertility gap. Further, we find that a husband's preferences, in terms of his ideal family size and preference for a son, significantly shape the fertility gap. Our results point to the need for accounting for gender norms and household perspective in fertility analysis and policy settings.
\end{abstract}

Keywords: fertility, India, fertility gap, son preference, household bargaining

JEL Codes: D10 J13 J16

${ }^{1}$ School of Economics and Finance, RMIT University

${ }^{2}$ Department of Economics, Monash University, Clayton VIC 3800, Australia. Phone: +613 9905 2305. Email: jaai.parasnis@monash.edu

(C) 2018 Ankita Mishra and Jaai Parasnis

All rights reserved. No part of this paper may be reproduced in any form, or stored in a retrieval system, without the prior written permission of the author.

monash.edu/ businesseconomics

ABN 12377614012 CRICOS Provider No. 00008C

AACSB $\frac{1}{\text { EQUMIS }}$ 


\section{Introduction}

Fertility gap is the difference between a woman's ideal number of children and her actual number of children. Despite the gains in maternal and child health and rapid socio-economic development, Figure 1 shows that fertility gap was prevalent in India in 2005-06 and remains so for the majority of women 10 years later. Fertility gap exists in both directions; a proportion of women have less than their desired number of children (positive fertility gap) and the majority have more children than desired (negative fertility gap). This motivates us to explore the factors impeding women from achieving their ideal number of children.

\section{INSERT FIGURE 1 HERE}

Availability of and access to modern birth control measures provide an opportunity for women not to exceed their desired level of fertility. Indeed, contraception knowledge and access is considered to be a major reason for women exceeding their desired number of children and, hence, has been the focus of academic studies and policymakers, particularly in developing countries. These efforts have borne fruit; by 2005-06, 98 percent of women aged 15-49 knew one or more methods of contraception and 81 percent of women aged 40 and over had used contraception (IIPS \& Macro International, 2007). Similar declines in prevalence and magnitude of a negative fertility gap (women exceeding their ideal number of children) should be observed if contraception access is the major barrier in women realising their desired fertility level. In light of the persistence of fertility gap, as documented in Figure 1, we extend the analysis of fertility gap to explore the role of gender preferences.

On the other hand, studies on positive fertility gap — that is, women having less children than desired - have focused mainly on developed countries. The main explanation, so far, is adverse economic conditions (Adsera, 2006, 2011). Lack of economic resources and security leads to postponement and, ultimately, failure to achieve desired fertility. In a low fertility setting of the United States, Morgan and Rackin (2010) find high congruence between intentions and completed fertility in aggregate and that underachieving desired fertility is more likely than overachieving. We provide a useful comparison by analysing fertility gap in India, a country with high but declining fertility during a period of economic development, and contribute to the literature by focusing on other possible channels leading to a positive fertility gap.

We explore gender norms as an explanation for deviations from the ideal number of children, employing two indicators of gender inequality in India: son preference and husband's fertility 
preferences. We propose that unlike other explanations of fertility gap, these variables contribute to fertility gap in both directions. That is, they have a potential to explain why women exceed their desired fertility, as well as why they stop short of their desired fertility level.

The first gender norm we consider is preference for sons. Cultural, religious and social institutions led to pervasive preference for sons through Indian society. Studies have documented wide-ranging effects of son preference, including gender-biased parental investments (Anukriti et al., 2016), choices regarding number and composition of children (Arnold et al., 1998; Clark, 2000; Chaudhuri, 2012), child health (Jayachandran \& Pande, 2017) and maternal health (Milazzo, 2018). In addition to the stated son preference (answers to questions about desired number of sons and daughters), we employ indicators of actual gender composition of children (proportion of daughters and gender of first and second child) to comprehensively capture son preference.

Despite a recognition that fertility is a negotiated outcome within a household, studies of fertility gap analyse it as a woman's outcome without accounting for the partner's preferences. Using longitudinal couples' data for Italy, Testa et al (2014) show the importance of considering both partners’ views in fertility models. Rasul (2008) develops a theoretical model of household bargaining over fertility and finds empirical support using Malaysian data. The analysis shows that couples bargain without commitment and that the influence of each spouse's fertility preference on fertility outcome depends on the relevant threat point and distribution of bargaining power. Ibisomi and Odimegwu (2011) provide qualitative evidence that husbands are 'in charge' (emphasis as per original reference) of decisions regarding number of children in Nigera. This leads us to the second aspect of gender norms in the present analysis, which is husband's fertility preference. In the context of the strong patriarchal structure of the Indian society and social norms emphasising the weak position of women within marriage, bargaining power is concentrated in the husband (Weitzman, 2014). Forrest et al (2007) document the use of violence by men to resolve disagreements over the use of contraception by imposing their fertility preferences on their partners in India. Hence, it is important to account for the husband's fertility preferences in fertility outcomes, which would be as influential as the woman's preferences, if not more.

We contribute to the literature in two important ways. First, we show the prevalence and distribution of fertility gap in the context of India. The existence of both positive and negative gap in our data leads us to explore the main factors contributing to fertility gap. Second, we 
show the importance of gender norms in shaping the fertility gap. Son preference and the husband's fertility preference significantly drive the fertility gap. Unlike factors such as contraception and economic resources emphasised in the literature on fertility gap so far, these variables significantly explain fertility gap in both directions. In a wider implication of this study, we draw attention to the importance of accounting for gender norms and a couple's, rather than an individual's, preferences in fertility analysis. We discuss implications of our findings for population and health policies and suggest future direction for policy focus in India.

\section{Data and Descriptive Statistics}

We employ data from the National Family Health Survey (NFHS) conducted by the International Institute for Population Sciences (IIPS) under The Ministry of Health and Family Welfare (MOHFW), Government of India. This large-scale, multi-round survey is conducted in a representative sample of households throughout India. We employ the latest two rounds: NFHS 3, conducted in 2005-06, and NFHS 4, conducted in 2015-16. While the survey covers all 29 states of India, we include 17 states in this present analysis. ${ }^{1}$ The survey provides detailed information on fertility for women aged 15-49. We restrict our sample to women aged 40 years and above, as the aim is to analyse the gap arising in ideal and actual family sizes once a woman has completed her fertility. The mean age of women at first birth is 20-21 years and age-specific fertility rates in the five-year period before the survey is two births per 1,000 for women aged 40-44 (IIPS \& ICF, 2017). Consequently, women complete their fertility by their late 30s. We also use data from men's questionnaire, which was administered in a subsample of households selected for the state module.

\section{INSERT TABLE 1 HERE}

The distribution of fertility gap, along with the distribution of ideal number of children and actual number of children, is reported in Table 1.35 percent of women in 2005-06 (NFHS 3) report no fertility gap, increasing to 43 percent 10 years later (NFHS 4). The majority of women report a fertility gap, which exists in both directions. Fertility gap ranges from -2 to 2 for 87-89 percent of women. The negative fertility gap clearly dominates: 53 percent in NFHS 3 and 44 percent in NFHS 4 exceed their ideal number of children. The norm for ideal fertility

\footnotetext{
${ }^{1}$ The 17 major states included in our analysis account for roughly 90 percent of India's population and make up around 87 percent of India's GDP. The remaining 11 states, not included in the analysis, were small with missing or unreliable data points. The states not included are Chhattisgarh, Jharkhand, Uttrakhand Goa, Mizoram, Sikkim, Arunanchal Pradesh, Meghalaya Jammu, Kashmir and Nagaland.
} 
is clearly two children. However, consistent with the dominance of negative fertility gap, only 27 percent in NFHS 3 and 30 percent in NFHS 4 have two children. 27 percent have three children across both time periods and a further 17 percent have four children. Table 2 provides descriptive statistics for all variables included in the analysis.

\section{INSERT TABLE 2 HERE}

23 percent of women and a similar proportion of men in NFHS 3 state son preference; that is, their ideal number of boys exceeds ideal number of girls. This share increases to 26 percent of women and 27 percent of men in NFHS 4. While this seems like an increase in son preference over the 10-year period, it is important to note the differences in the distribution of NFHS 3 and NFHS 4 sample. Compared to NFHS 3, more households in NFHS 4 come from rural areas (69 percent, versus 49 percent in NFHS 3) and from northern states (57 percent, versus 41 percent in NFHS 3). These geographical locations are associated with stronger son preference. Table A5 in the appendix reports fertility and son preference by state for both rounds of data and we control for regional effects in all estimations.

\section{INSERT FIGURE 2 HERE}

Figure 2 illustrates the relationship between fertility and son preference. The association with women's son preference is shown in the top left panel (2a for NFHS 3 and 2b for NFHS 4). Women who state preference for sons also express a desire for more children (three children), compared to women who express no son preference (two children). These women also have more children (four on average) compared to three children for women who state no son preference. Fertility gap, though negative for both groups, is larger for women with son preference than for women with no son preference in NFHS 3. The difference between two groups is smaller in NFHS 4, but women stating no son preference have a larger fertility gap. The association with the husband's son preference (Figures 2c and 2d) is shown in the lower panel. Men who state a preference for sons have higher desired number of children, higher actual number of children and a larger fertility gap. Table 2 shows that on average, men's ideal number of children is greater than women's ideal number of children.

\section{INSERT FIGURE 3 HERE}

The role of son preference in shaping fertility gap is further supported by Figure 3, which plots fertility gap against the number of daughters in a family. As the number of daughters increases, the actual number of children increases; women have larger families. In contrast, regardless of the number of daughters, the desired number of children remains stable around two to four 
children. The fertility gap is negative and increases with the number of daughters. However, women with more daughters are not driven by a desire for more children, which suggests that they have larger families to fulfil a desire for sons.

Figure A1 in the appendix plots average fertility gap, ideal number of children and actual number of children against socio-economic variables. Average fertility is plotted against women's education level in the left panel (Panel A) and against the household's economic status in the right panel (Panel B) for NFHS $3 .^{2}$ These figures reveal the following salient features:

(i) Both the desired fertility and actual fertility fall with an increase in education levels. Better educated women want smaller families and have smaller families.

(ii) However, fertility gap is negative across all education levels. Women, on average, have more children than their stated ideal.

(iii) The average negative fertility gap decreases with women's education. It is important to note low education levels in India, particularly for women. Even in NFHS 4, 51 percent women have no education and the mean years of education for women aged 40 and over is four. A household's economic status has a similar effect on fertility as women's education. The fertility gap is negative across household economic status. This gap declines with better economics status as both, desired fertility and actual fertility, decline.

In the following section, we detail the empirical strategy to look at the contribution of each factor-particularly son preference and husband preference-to fertility gap and explore the differences across positive, zero and negative fertility gap.

\section{Empirical Strategy}

Let $y_{i t}$, defined as the difference between ideal number of children and the actual number of children, denote the fertility gap for women $i$ at time $t . y_{i}$ is negative if a woman exceeds her ideal family size, positive if she does not achieve her desired number of children, and zero if the actual number of children is equal to her stated ideal.

Our basic empirical specification is of the form:

$$
y_{i t}=\alpha_{i t}+\beta X_{i t}+\varepsilon_{i t}
$$

\footnotetext{
${ }^{2}$ The pattern is similar for NFHS 4; hence, not shown here. Figures for NFHS 4 are available from the authors.
} 
Following the discussion in the preceding sections, the key variables of interest in $X_{i t}$ are as follows.

(i) Son preference as measured by a woman's stated son preference measure and the proportion of daughters. Son preference measure takes the value 1 if the ideal number of boys exceeds ideal number of girls and is equal to zero otherwise. Proportion of daughters reflects the number of daughters as a proportion of total children for the woman.

(ii) Couple's fertility preferences. This includes two sets of measures. First, we include son preference for the woman and her husband. We also include the husband's ideal number of children to capture his preference for family size. Second, we control for the difference in fertility preferences within the couple. This includes the difference between the husband's ideal number of children and the wife's ideal number of children (difference in ideal no. of children) and the difference between the husband's and wife's stated son preference (difference in son preference). The variable, difference in son preference, is a binary variable and equal to 1 if the woman and her husband have different values for son preference, and 0 if there is no disagreement on number of preferred sons in their ideal family size.

The other control variables included in $X_{i t}$ are the woman's characteristics, husband's characteristics and household characteristics. We control for the woman's education, age, work status, age at first birth, exposure to media and number of marital years. We also include contraception use. The husband's characteristics include age, education and work status; household characteristics include household size, economic status, religion of the head and ethnicity. We further control for rural and geographical (or regional) fixed effects.

We estimate the model using multinomial logit (MNL). This method accounts for the fact that the dependent variable — fertility gap—consists of three distant categories: positive gap, no gap and negative gap. These categories have no natural order and the variables are alternativeinvariant. Multinomial estimations enhance our understanding of the drivers of fertility gap as direction and significance of the explanatory variables can differ across fertility gap.

Let $y_{i} \in\{1,2,3\}$ denote the stated fertility gap outcome $(y)$ for individual $i$ and $X$ denote the explanatory variables. We use 1 to denote negative fertility gap, 2 for no fertility gap and 3 for 
positive fertility gap. Using MNL, the probability that alternative fertility outcome $j$ occurs is $p_{j}=\operatorname{Pr}[y=j], j=1,2,3$ and given as:

$p_{i j}=\frac{e^{x_{i j}^{\prime} \beta}}{\sum_{l=1}^{m} e^{x_{i l}^{\prime} \beta}} \quad$ where $j=1,2,3$

Since $\sum_{j=1}^{m} p_{j}=1$, model identification requires that the parameter $\beta$ corresponding to the base category is set to 0 . We use $j=2$ (no fertility gap) as the base category.

For an unordered multinomial model, there is no single conditional mean of the dependent variable $y$; rather, there are $m$ outcomes. Therefore, it is more useful to compute marginal effects (MEs) for these models, which measure the change in probabilities of $m$ outcomes as regressors change. After estimating equation (2) using maximum likelihood, marginal effects (ME) are computed as

$\frac{\partial p_{i j}}{\partial x_{i}}=p_{i j}\left(\beta_{j}-\bar{\beta}_{i}\right)$

where $\bar{\beta}_{i}=\sum_{l} p_{i l} \beta_{l}$.

For a variable $x$, the ME is positive if $\beta_{j}>\bar{\beta}_{l}$. The MEs vary with the point of evaluation, $x_{i}$. The MEs reported here are 'marginal effects at the mean' where we obtain the ME on $\operatorname{Pr}(y=j)$ of a change in an associated regressor when all the other regressors are kept at their sample mean. It has to be noted that MEs are computed differently for continuous and discrete variables. For discrete variables, 'marginal effects at the mean' measures how $\operatorname{Pr}(y=j)$ changes when the discrete variable changes from 0 to 1 , keeping all other variables at their sample mean. For continuous variables, 'marginal effects at the mean' measures how $\operatorname{Pr}(y=j)$ changes when the continuous variable increases by one unit, keeping all other variables at their sample mean. We calculate and report the average marginal effects that are obtained by calculating a marginal effect for each case and averaging all the computed effects. Table A1 in the appendix reports definitions of all variables employed in this analysis.

\section{Results}

\section{Son preference and fertility gap}

To provide context for the reported results, note that fertility gap is defined as the ideal number of children minus the actual number of children. Thus, a negative gap means that a woman has more than desired number of children and a positive gap exists when she has less children than she desired. The gap is negative on average. We first estimate the effect of son preference and 
report average marginal effects from multinomial logit estimations in Table 3. Consistent with the literature so far, we start with concentrating on women's preferences only.

\section{INSERT TABLE 3 HERE}

Results for NFHS 3 and NFHS 4 are consistent despite the 10-year time period and difference in samples. The two measures of son preference in Panel A exhibit contrasting effects. Son preference decreases the probability of a negative fertility gap and increases the probability of no fertility gap and a positive fertility gap. In NFHS 3, having a preference for son decreases the probability of having more children than desired by 12 percent and increases the probability of a woman meeting her desired number of children by nine percent. These effects decrease to around nine percent and seven percent, respectively, in NFHS 4, but remain significant. Overall, women with son preference are more likely to have their desired number of children rather than exceeding their target. These results, while seemingly counter to the discussion so far, are investigated further.

Contrary to women's stated son preference, the proportion of daughters has a significant effect across the fertility gap, which is consistent with son-preferring behaviour. More daughters increases the probability of having more children than desired and reduces the probability of having the desired number of children or less than desired number of children. Figure 3 shows that this change in fertility is driven by an increase in the number of children a woman has, rather than by a change in her desired number of children. Thus, an increase in proportion of daughters induces a woman to have more children. The above estimated effect of stated son preference suggests that women with son preference are more likely to meet their desired fertility or stay under, however, the fertility response to proportion of daughters in the family suggests the opposite.

The effect of the direction of son preference on fertility gap is consistent with two further explanations. First, the possibility is that women engage in stopping behaviour or son-targeting fertility behaviour (Basu \& De Jong, 2010; Rosenblum, 2013). That is, regardless of their ideal family size, women stop once they have their desired number of sons. This explanation is germane given the significant effect of the proportion of daughters. Second, this relationship could be reflecting an association between son preference and family size. Since the desired number of children is higher for women with son preference, they are less likely to exceed their desired fertility. On the other hand, studies such as Bhat and Xavier (2003) and Jayachandran 
(2017) show that desired sex ratio increases as fertility falls. Both of these channels are investigated further in the following section.

We first investigate stopping or son-targeting fertility behaviour by including dummies for the gender of first-born and second-born children as additional explanatory variables in the next specification. Results are reported in Panel B of Table 3. Results for son preference and proportion of daughters are comparable to those in Panel A. Having a first child who is male significantly reduces the probability of a woman exceeding her desired fertility, while increasing the probability of achieving exactly her desired number of children (by almost the same magnitude). The effect is similar when the second child is male. Given that women want 2.4 children on average, this suggests that she is not likely to exceed her desired fertility if she has sons within the first two births. This shows that son preference does have a significant effect on fertility gap; however, it is important to look at the actual gender composition of children in addition to the stated preference to capture its full impact.

\section{Husband's preferences}

Next, we probe the role of the husband's preferences in explaining fertility gap for women. We look at the husband's son preference and ideal family size to capture his fertility preferences in specification 3 of the model. This specification includes all four measures of son preference as discussed earlier, along with the husband's fertility preferences.

\section{INSERT TABLE 4 HERE}

We show that the husband's preferences, so far ignored in the literature, play a significant role in fertility gap. The estimates for the husband's preferences are reported in Panel A of Table 4. A woman is likely to exceed her desired number of children (and less likely to have no fertility gap) by three percent if her husband prefers a higher number of sons than daughters. This effect remains significant and increases to four percent almost 10 years later in NFHS 4. Likewise, increase in the husband's ideal family size increases the probability of women exceeding their desired family size by three percent and reduces the probability of meeting the target by similar percentages across both NFHS rounds.

\section{Within-couple differences in fertility preferences}

Last, Panel B in Table 4 investigates the role of within-couple differences in fertility preferences. This is the most general specification that includes all four previously stated measures of son preference, along with the husband's fertility preferences and within-couple differences in fertility. Differences in husbands' and women's ideal number of children 
significantly affects the fertility gap. An increase in husbands' ideal number of children, over women's, increases the probability of a negative fertility gap by 24 percent in NFHS 3 and 22 percent in NFHS 4. On the other hand, it reduces the probability of meeting the woman's desired family size (by around 15 percent) and the probability of having less children than the woman's desired number (by around seven percent) in both time periods. On average, women's ideal number of children is 2.4 in both rounds of NFHS. The desired number of children is higher for men: 2.43 in NFHS 3 and 2.55 in NFHS 4. Our estimates show that when a couple differs in their ideal family size, women are more likely to have more children than desired. Similarly, about 27 percent of men and women express son preference. If there is disagreement within the couple about son preference, the woman is five percent more likely to have a negative fertility gap and six to seven percent less likely to have her ideal number of children. Thus, a within-couple difference in son preference takes a woman away from her desired family size.

Explicitly including the husband's ideal number of children, along with within-couple difference on ideal family size, seems to give rise to contrasting effects on actual fertility outcomes for women. Though the husband's ideal number of children has a significant effect on each type of fertility outcome, an increase in the husband's ideal number of children makes it more likely for women to either meet or underachieve and less likely to exceed her desired children, resulting in smaller families. In contrast to that, if there is disagreement between husband and wife on ideal family size and the husband's ideal family size is more than that of the woman, she is $22-24$ percent more likely to exceed her desired number of children, 15-16 percent less likely to meet her desired number of children and seven percent less likely to undershoot her desired children across both NFHS rounds.

In order to further understand the aforementioned conflicting results, we estimated the alternative specification as given by Equation (4), where we attempt to investigate the effect of variables of interest on women's actual fertility outcomes, rather than the gap. Those results are discussed below.

\section{Further results}

To investigate the influence of desired family size suggested in the literature (discussed in Section 4), we estimate an alternative specification directly controlling for desired family size. An alternative way of estimating fertility gap is

$h_{i t}=a_{i t}+\beta_{1} X_{i t}+\beta_{2}$ Desired_children $_{i t}+e_{i t}$ 
where $h_{i t}$ is the (actual) number of children for the woman $i$ at time $t$, Desired_children $n_{i t}$ is the ideal number of children for the woman $i$ at time $t$ and $X_{i t}$ contains explanatory variables discussed above. Equation (4) is estimated using OLS regression.

\section{INSERT TABLE 5 HERE}

Table 5 reports results for Equation (4) with the ideal number of children as an explanatory variable for two model specifications. First, all measures of son preference are significant and show that son preference leads to an increase in the number of children a woman has, controlling for her desired number of children. A higher proportion of daughters increases the number of children, while first or second male child reduces the number of children between 20 to 30 percent. Women's son preference increases the number of children and is statistically significant for NFHS 4. The husband's son preference has a similarly significant effect on the number of children.

Second, these results reinforce the importance of the husband's preferences. The husband's son preference and increase in his ideal number of children increases the actual number of children. Note that inclusion of the husband's ideal number of children leads to women's ideal number of children being omitted owing to collinearity. Within-couple difference in ideal number of children has a significant positive effect, increasing the number of children (columns (1) and (2)). However, controlling for women's and husbands' ideal number of children separately, (columns (3) and (4)), this within-couple difference is associated with a lower number of children. Difference in son preference is positive and significant in NHFS 4.

The effects of control variables are consistent with those in the literature. The full set of results is reported in A2. Probability of no fertility gap increases with women's education and media exposure. If the age of the woman at the birth of her first child increases, she is more likely to meet her desired number of children or to have less children than desired. She is two to three percent less likely to exceed her desired number of children; thus, an increase in age at first birth leads to smaller families. While the husband's fertility preferences are significant, as discussed above, his age, education or employment status are not statistically significant. Women from Hindu households and from better economic status (middle-rich households) are more likely to have no fertility gap. Significant regional effects consistent with those that have been documented for India (Bongaarts, 2013) are observed; households in northern regions have bigger families, while households in southern regions have smaller families. 
We conduct further robustness checks to address potential sensitivity of our results. We estimate OLS regression, treating fertility gap as a continuous variable as a robustness check. The results, reported in Table A3, are consistent with multinomial logit estimations. To check the sensitivity to sample restricting women 40 years and above, we re-estimate the model by including all women (aged 15 and over). These results are available from the authors and are consistent with those reported here. So far, we analyse NFHS 3 and NFHS 4 separately to allow for difference in samples and comparison over time. We pool data from NFHS 3 and NFHS 4 together, controlling for time effects. Results, reported in Table A4, are consistent with those reported in the main analysis.

One potential concern is the use of ultrasound for sex determination, affecting both the composition and size of a family (see Arnold et al., 2002; Anukriti et al., 2016). NFHS 3 and NFHS 4 ask whether ultrasound was conducted during pregnancy if a birth or termination is registered. In our sample of women aged 40 and above, this variable is available for only seven percent of the sample in NFHS 3 and five percent in NFHS $4 .{ }^{3}$ Further, a woman aged 40 (and over) in NFHS 3 data had children in the mid-1980s (or earlier). Ultrasound use just began to emerge and access was limited during this period and use of this technology for sex selection became feasible much later (Anukriti et al., 2016). Ultrasound access becomes more evident at the population level after 1985 and is more widespread by the mid-1990s. While this is during the child-bearing period for women in the NFHS 4 sample, the fact that our results are consistent across NFHS 3 and NFHS 4 shows that our analysis is robust to this concern.

The analysis uses ideal number of children to define fertility gap. There is a possibility that responses to questions about ideal number of children could be subject to an aversion to offering an ideal that is less than the already attained number of children; that is, to rationalisation (Casterline \& AgyeiMensah, 2017; Bongaarts \& Casterline, 2013). While this effect could be stronger for older women who have been married for many years, this concern is moderated by the fact that our results are consistent when we include all women aged 15 and over. Further, if the rationalisation is strongly present, we should observe no or little fertility gap. However, we observe significant fertility gap and the gap is negative on average; women state they have more children than desired. Thus, to the extent that rationalisation is applicable, our results provide a lower bound on the effects on fertility gap.

\footnotetext{
${ }^{3}$ In the full sample, this variable is available for 36 percent of women in NFHS 3 and 32 percent of women in NFHS 4.
} 


\section{Discussion}

We document that a majority of women experience fertility gap and show the importance of gender norms in shaping this fertility gap in the context of India. The first gender norm we consider is son preference. The analysis employs four indicators of son preference and presents consistent evidence on the significant effect on fertility gap. Women exceed their desired number of children in order to satisfy their preference for sons. On the other hand, women limit the number of children they have once they reach their desired number of sons, regardless of their desired fertility.

The second gender aspect affecting fertility gap is the husband's preferences. While family formation is a negotiated outcome within a couple, studies on fertility gap have so far concentrated on women's fertility preferences. We find that the husband's fertility preferences, as well as differences in preferences within a couple, play a significant role in shaping fertility gap. The husband's preferences would be dominant in the Indian context owing to strong patriarchal norms. Our results show the importance of accounting for household bargaining in fertility decisions.

Fertility in India has been historically characterised by high fertility rate and son preference. Concentrated effort has led to a noticeable effect on fertility rate; the total fertility rate has declined from 3.4 children in 1992-93 to 2.2 children in 2015-16, just above the replacement rate of 2.1 (IIPS \& ICF, 2017). Table A5 in the appendix compares the ideal number of children and actual number of children across states for NFHS3 and NFHS 4. The actual number of children has declined across all states and the desired number of children has declined across most states. As discussed in Section 2, the fertility norm for family size is two, at most three, children. However, changes in son preference (Table A5) do not show similar declines. In NFHS 3, the states with the highest proportion of women expressing son preference are Bihar (43 percent), Rajasthan (40 percent) and Uttar Pradesh and Haryana (both at 35 percent). Rajasthan and Haryana show sizable declines in son preference by NFHS 4, falling to 29 percent and 22 percent, respectively. However, son preference in other high son preference states shows no such decline. In fact, the proportion of women with son preference increases in Bihar (45 percent in NFHS 4) and Utter Pradesh (44 percent in NFHS 4). Thus, while the norms regarding the number of children have changed, norms about their gender composition haven't changed to the same extent. 
Evidence in this study, in line with evidence from Jayachandran (2017), suggests a possibility for son preference behaviour to be pronounced during periods of fertility decline. There is now a need to focus research and policy efforts towards mitigating the son preference norms. The concentrated focus since the launch of the National Family Welfare Programme in 1951 has succeeded in reducing actual fertility as well as desired fertility, in terms of the number of children. A similar effort and focus is now needed towards changing the norms regarding son preference.

Our results for women's educational levels support findings by Pande and Astone (2007) regarding the significant role of women's education. Son preference, as well as desired and actual number of children, decline with women's education levels. 34 percent of women with no education express son preference, falling to 11 percent of women with tertiary education. This suggests a way of addressing the conundrum posed by declining fertility rates regarding son preference association. Given that only 21.5 of women complete 12 or more years of education in NFHS 4, there is a substantial margin to lift education levels and, thus, leverage its effect on gender norms.

\section{Conclusion}

Gender norms shaped by social and religious institutions are important for individuals and these norms, in turn, influence behaviours in the society. We show the importance of gender-biased preferences on fertility in India during 2005-06 to 2015-16. Women's actual number of children deviate from their ideal number of children consistent with their preference for sons. Further, the husband's fertility preferences significantly contribute to the fertility gap for women, the difference between her ideal and actual number of children. These results contribute to fertility analysis and policy discussion by emphasising gender norms and household perspective as the channels shaping fertility gap. 


\section{References}

Adsera, A. (2006). An economic analysis of the gap between desired and actual fertility: The case of Spain. Review of Economics of the Household, 4(1), 75-95.

Adsera, A. (2011). The interplay of employment uncertainty and education in explaining second births in Europe. Demographic Research, 25(16), 513-544.

Anukriti, S., Bhalotra, S. R. \& Tam, H. F. (2016). On the quantity and quality of girls: New evidence on abortion, fertility, and parental investments. IZA Discussion Paper No. 10271.

Arnold F., Choe, M. K. \& Roy, T.K. (1998). Son preference, the family-building process and child mortality in India. Population Studies, 52(3), 301-315.

Arnold, F., Kishor, S., \& Roy, T. K. (2002). Sex-selective abortions in India. Population and Development Review, 28(4), 759-785.

Basu, D., \& De Jong, R. (2010). Son targeting fertility behavior: Some consequences and determinants. Demography, 47(2), 521-536.

Bhat, P. M., \& Zavier, A. F. (2003). Fertility decline and gender bias in Northern India. Demography, 40(4), 637-657.

Bongaarts, J., \& Casterline, J. (2013). Fertility transition: Is sub-Saharan Africa different? Population and Development Review, 38, 153-168.

Casterline, J. B., \& Agyei-Mensah, S. (2017). Fertility desires and the course of fertility decline in sub-Saharan Africa. Population and Development Review, 43, 84-111.

Chaudhuri, S. (2012). The desire for sons and excess fertility: A household-level analysis of parity progression in India. International Perspectives on Sexual and Reproductive Health, 38(4), 178-186.

Clark, S. (2000). Son preference and sex composition of children: Evidence from India. Demography, 37(1), 95-108.

Forrest, W., Arunachalam, D., \& Navaneetham, K. (2018). Intimate partner violence and contraceptive use in India: The moderating influence of conflicting fertility preferences and contraceptive intentions. Journal of Biosocial Science, 50(2), 212-226.

Ibisomi, L., \& Odimegwu, C. (2011). Understanding resolution of differential fertility preferences among couples in Nigeria. International Journal of Business and Social Science, 2(4), 98-105. 
International Institute for Population Sciences (IIPS) \& Macro International. (2007). National Family Health Survey (NFHS-3), 2005-06: India: Volume I. Mumbai: IIPS.

International Institute for Population Sciences (IIPS) \& ICF (2017). National Family Health Survey (NFHS-4), 2015-16: India. Mumbai: IIPS.

Jayachandran, S. (2017). Fertility decline and missing women. American Economic Journal: Applied Economics, 9(1), 118-39.

Jayachandran, S., \& Pande, R. (2017). Why are Indian children so short? The role of birth order and son preference. American Economic Review, 107(9), 2600-2629.

Milazzo, A. (2018). Why are adult women missing? Son preference and maternal survival in India. Journal of Development Economics, 134, 467-484.

Morgan, S. P., \& Rackin, H. (2010). The correspondence between fertility intentions and behavior in the United States. Population and Development Review, 36(1), 91-118.

Pande, R., \& Astone, N. (2007). Explaining son preference in rural India: The independent role of structural versus individual factors. Population Research and Policy Review, 26(1), 1-29.

Rasul, I. (2008). Household bargaining over fertility: Theory and evidence from Malaysia. Journal of Development Economics, 86(2), 215-241.

Rosenblum, D. (2013). The effect of fertility decisions on excess female mortality in India. Journal of Population Economics, 26(1), 147-180.

Testa, M. R., Cavalli, L., \& Rosina, A. (2014). The effect of couple disagreement about child timing intentions: A parity-specific approach. Population and Development Review, 40(1), 3153.

Weitzman, A. (2014). Women's and men's relative status and intimate partner violence in India. Population and Development Review, 40(1), 55-75. 
Table 1: Distribution of fertility gap, ideal number of children and actual number of children

\begin{tabular}{|c|c|c|c|c|c|c|c|}
\hline & \multicolumn{7}{|c|}{$\%$ of women } \\
\hline & \multicolumn{2}{|c|}{ Fertility gap } & \multirow[b]{2}{*}{ No of children } & \multicolumn{2}{|c|}{ Ideal no of children } & \multicolumn{2}{|c|}{ Actual no of children } \\
\hline Fertility gap & NFHS 3 & NFHS 4 & & NFHS 3 & NFHS 4 & NFHS 3 & NFHS 4 \\
\hline-11 & 0.03 & & 0 & 1.23 & 4.79 & 2.28 & 2.21 \\
\hline-10 & & 0.01 & 1 & 6.27 & 3.73 & 7.34 & 7.39 \\
\hline-9 & 0.02 & 0.04 & 2 & 58.98 & 52.85 & 26.99 & 29.54 \\
\hline-8 & 0.02 & 0.03 & 3 & 21.7 & 22.58 & 27.37 & 27.03 \\
\hline-7 & 0.21 & 0.17 & 4 & 9.66 & 13.41 & 16.93 & 16.75 \\
\hline-6 & 0.43 & 0.38 & 5 & 1.35 & 1.57 & 9.02 & 8.6 \\
\hline-5 & 1.64 & 1.04 & 6 & 0.59 & 0.76 & 5.27 & 4.77 \\
\hline-4 & 3.21 & 2.7 & 7 & 0.09 & 0.13 & 2.44 & 2.39 \\
\hline-3 & 6.96 & 6.11 & 8 & 0.05 & 0.09 & 1.56 & 0.84 \\
\hline-2 & 15.24 & 11.96 & 9 & 0.02 & 0.01 & 0.52 & 0.32 \\
\hline-1 & 25 & 21.83 & 10 & 0.03 & 0.04 & 0.19 & 0.12 \\
\hline 0 & 35.06 & 43.51 & 11 & & 0.01 & 0.05 & 0.02 \\
\hline 1 & 8.5 & 9.16 & 12 & 0.20 & 0.02 & 0.02 & 0.01 \\
\hline 2 & 2.76 & 2.57 & 13 & & 0.01 & & \\
\hline 3 & 0.59 & 0.36 & 14 & 0.20 & & & \\
\hline 4 & 0.16 & 0.1 & 15 & & & 0.20 & \\
\hline 5 & 0.07 & 0.03 & & & & & \\
\hline 6 & 0.02 & 0.01 & & & & & \\
\hline 7 & 0.05 & & & & & & \\
\hline 8 & 0.02 & & & & & & \\
\hline 9 & & 0.01 & & & & & \\
\hline Total & 100 & 100 & & 100 & 100 & 100 & 100 \\
\hline Observations & 5,787 & 11,523 & & 5,787 & 11,523 & 5,787 & 11,523 \\
\hline
\end{tabular}


Table 2: Descriptive statistics

\begin{tabular}{|c|c|c|}
\hline Variable & NFHS 3 & NFHS 4 \\
\hline \multicolumn{3}{|l|}{ Son Preference } \\
\hline Women reporting son preference (\%) & 23.16 & 26.46 \\
\hline Men reporting son preference (\%) & 23.19 & 26.99 \\
\hline Proportion (\%) of Daughters: Mean & 44.27 & 43.67 \\
\hline (Std dev) & $(30.19)$ & $(29.64)$ \\
\hline First Child Male (\% women) & 47.41 & 47.22 \\
\hline Second Child Male (\% women) & 48.19 & 48.43 \\
\hline \multicolumn{3}{|l|}{ Preferences within couple } \\
\hline $\begin{array}{l}\text { Woman's ideal family size: Mean } \\
\text { (Std Dev) }\end{array}$ & $\begin{array}{r}2.40 \\
(0.93)\end{array}$ & $\begin{array}{r}2.45 \\
(1.08)\end{array}$ \\
\hline $\begin{array}{l}\text { Man’s ideal family size: Mean } \\
\text { (Std Dev) }\end{array}$ & $\begin{array}{r}2.43 \\
(1.02)\end{array}$ & $\begin{array}{r}2.55 \\
(1.14)\end{array}$ \\
\hline $\begin{array}{l}\text { Man’s ideal family size - Woman’s ideal family size: Mean } \\
\text { (Std Dev) }\end{array}$ & $\begin{array}{r}0.03 \\
(1.15)\end{array}$ & $\begin{array}{r}0.10 \\
(1.27)\end{array}$ \\
\hline \multicolumn{3}{|l|}{ Woman’s Characteristics } \\
\hline Ever used any modern method of contraception (Yes \%) & 81.37 & 75.63 \\
\hline $\begin{array}{l}\text { Age (in years): Mean } \\
\text { (Std Dev) }\end{array}$ & $\begin{array}{r}43.32 \\
(2.72)\end{array}$ & $\begin{array}{r}43.68 \\
(2.81)\end{array}$ \\
\hline $\begin{array}{l}\text { Education (in years): Mean } \\
\text { (Std Dev) }\end{array}$ & $\begin{array}{r}4.78 \\
(5.30)\end{array}$ & $\begin{array}{r}4.09 \\
(4.96)\end{array}$ \\
\hline $\begin{array}{l}\text { Age at first birth (in years): Mean } \\
\text { (Std Dev) }\end{array}$ & $\begin{array}{r}20.47 \\
(4.03)\end{array}$ & $\begin{array}{r}20.94 \\
(4.12)\end{array}$ \\
\hline $\begin{array}{l}\text { Marital years: Mean } \\
\text { (Std Dev) }\end{array}$ & $\begin{array}{l}24.79 \\
(4.78)\end{array}$ & $\begin{array}{l}24.84 \\
(4.85)\end{array}$ \\
\hline Currently working (\%) & 41.09 & 70.41 \\
\hline Exposure to Media: No exposure (\%) & 27.99 & 30.87 \\
\hline \multicolumn{3}{|l|}{ Husband's Characteristics } \\
\hline $\begin{array}{l}\text { Age (in years): Mean } \\
\text { (Std Dev) }\end{array}$ & $\begin{array}{l}47.88 \\
(3.60)\end{array}$ & $\begin{array}{r}47.76 \\
(3.92)\end{array}$ \\
\hline $\begin{array}{l}\text { Education (in years): Mean } \\
\text { (Std Dev) }\end{array}$ & $\begin{array}{r}7.48 \\
(7.19)\end{array}$ & $\begin{array}{r}6.73 \\
(6.58)\end{array}$ \\
\hline Currently working (\%) & 97.75 & 96.44 \\
\hline \multicolumn{3}{|l|}{ Household Characteristics } \\
\hline $\begin{array}{l}\text { Size: Mean } \\
\text { (Std Dev) }\end{array}$ & $\begin{array}{r}5.47 \\
(2.59)\end{array}$ & $\begin{array}{r}5.31 \\
(2.31)\end{array}$ \\
\hline Ethnicity: Belonging to Scheduled Class or Tribe (\%) & 21.95 & 30.64 \\
\hline Wealth Status: Poor-Poorest (\%) & 22.19 & 35.95 \\
\hline Rural (\%) & 48.56 & 68.69 \\
\hline \multicolumn{3}{|l|}{ Sample Characteristics } \\
\hline Religion: Hindu (\%) & 82.89 & 84.02 \\
\hline \multicolumn{3}{|l|}{ Region (\%) } \\
\hline North & 40.69 & 56.93 \\
\hline South & 48.76 & 22.53 \\
\hline East & 10.54 & 20.54 \\
\hline
\end{tabular}


Table 3: Son Preference and fertility gap (Average Marginal Effects from Multinomial Logit Estimation)

\begin{tabular}{|c|c|c|c|c|c|c|}
\hline \multirow[b]{2}{*}{ Dependent Variable: Fertility Gap } & \multicolumn{3}{|c|}{ NFHS 3} & \multicolumn{3}{|c|}{ NFHS 4} \\
\hline & Negative Gap & No Gap & Positive Gap & Negative Gap & No Gap & Positive Gap \\
\hline \multicolumn{7}{|l|}{ Panel A } \\
\hline Son preference & $\begin{array}{r}-0.125^{* * *} \\
(0.015)\end{array}$ & $\begin{array}{r}0.089 * * * \\
(0.015)\end{array}$ & $\begin{array}{r}0.036^{* * *} \\
(0.009)\end{array}$ & $\begin{array}{r}-0.095^{* * *} \\
(0.010)\end{array}$ & $\begin{array}{r}0.074^{* * *} \\
(0.010)\end{array}$ & $\begin{array}{r}0.021^{* * *} \\
(0.006)\end{array}$ \\
\hline Proportion of daughters & $\begin{array}{r}0.002^{* * *} \\
(0.000)\end{array}$ & $\begin{array}{r}-0.002^{* * *} \\
(0.000)\end{array}$ & $\begin{array}{r}-0.000 * * * \\
(0.000)\end{array}$ & $\begin{array}{r}0.003^{* * *} \\
(0.000)\end{array}$ & $\begin{array}{r}-0.002^{* * *} \\
(0.000)\end{array}$ & $\begin{array}{r}-0.001^{* * *} \\
(0.000) \\
\end{array}$ \\
\hline Observations & 5,665 & 5,665 & 5,665 & 11,304 & 11,304 & 11,304 \\
\hline \multicolumn{7}{|l|}{ Panel B } \\
\hline Son preference & $\begin{array}{r}-0.130 * * * \\
(0.015)\end{array}$ & $\begin{array}{r}0.084^{* * *} \\
(0.015)\end{array}$ & $\begin{array}{r}0.046 * * * \\
(0.007)\end{array}$ & $\begin{array}{r}-0.093 * * * \\
(0.010)\end{array}$ & $\begin{array}{r}0.050 * * * \\
(0.010)\end{array}$ & $\begin{array}{r}0.043 * * * \\
(0.005)\end{array}$ \\
\hline Proportion of daughters & $\begin{array}{r}0.001^{* * *} \\
(0.000)\end{array}$ & $\begin{array}{r}-0.001^{* * *} \\
(0.000)\end{array}$ & $\begin{array}{r}-0.000 \\
(0.000)\end{array}$ & $\begin{array}{r}0.001 * * * \\
(0.000)\end{array}$ & $\begin{array}{r}-0.001^{* * *} \\
(0.000)\end{array}$ & $\begin{array}{c}-0.000 * \\
(0.000)\end{array}$ \\
\hline First child male & $\begin{array}{r}-0.067 * * * \\
(0.017)\end{array}$ & $\begin{array}{r}0.068^{* * *} \\
(0.017)\end{array}$ & $\begin{array}{r}-0.001 \\
(0.009)\end{array}$ & $\begin{array}{r}-0.010 * * * \\
(0.012)\end{array}$ & $\begin{array}{r}0.096^{* * *} \\
(0.012)\end{array}$ & $\begin{array}{r}0.004 \\
(0.007)\end{array}$ \\
\hline Second child male & $\begin{array}{r}-0.041^{* *} \\
(0.016) \\
\end{array}$ & $\begin{array}{c}0.030 * \\
(0.016) \\
\end{array}$ & $\begin{array}{r}0.011 \\
(0.008) \\
\end{array}$ & $\begin{array}{r}-0.085^{* * *} \\
(0.011) \\
\end{array}$ & $\begin{array}{r}0.079 * * * \\
(0.012)\end{array}$ & $\begin{array}{r}0.007 \\
(0.006) \\
\end{array}$ \\
\hline Observations & 5,303 & 5,303 & 5,303 & 10,506 & 10,506 & 10,506 \\
\hline
\end{tabular}

Notes: Fertility gap defined as difference between ideal and actual number of children. Standard errors in parentheses. Multinomial logit estimations including controls for husband's age, education and employment status, woman's age, education employment status, media exposure and age at first birth, marital years, contraception use, rural location, region size, religion and social group (Scheduled Tribe/Class) of the household. *** $\mathrm{p}<0.01,{ }^{*} \mathrm{p}<0.05,{ }^{*} \mathrm{p}<0.1$ 
Table 4: Husband's preference and fertility gap (Average Marginal Effects from Multinomial Logit Estimation)

\begin{tabular}{|c|c|c|c|c|c|c|}
\hline \multirow[b]{2}{*}{ Dependent Variable: Fertility Gap } & \multicolumn{3}{|c|}{ NFHS 3} & \multicolumn{3}{|c|}{ NFHS 4} \\
\hline & Negative Gap & No Gap & Positive Gap & Negative Gap & No Gap & Positive Gap \\
\hline \multicolumn{7}{|l|}{ Panel A } \\
\hline \multirow[t]{2}{*}{ Son preference } & $-0.137 * * *$ & $0.091 * * *$ & $0.045^{* * *}$ & $-0.105^{* * *}$ & $0.061^{* * *}$ & $0.044^{* * *}$ \\
\hline & $(0.015)$ & $(0.015)$ & $(0.007)$ & $(0.010)$ & $(0.010)$ & $(0.005)$ \\
\hline \multirow[t]{2}{*}{ Proportion of daughters } & $0.001 * * *$ & $-0.001^{* * *}$ & -0.000 & $0.001 * * *$ & $-0.001 * * *$ & $-0.000^{*}$ \\
\hline & $(0.000)$ & $(0.000)$ & $(0.000)$ & $(0.000)$ & $(0.000)$ & $(0.000)$ \\
\hline \multirow[t]{2}{*}{ First child male } & $-0.067 * * *$ & $0.068 * * *$ & -0.001 & $-0.101 * * *$ & $0.097 * * *$ & 0.004 \\
\hline & $(0.017)$ & $(0.017)$ & $(0.009)$ & $(0.012)$ & $(0.012)$ & $(0.007)$ \\
\hline \multirow[t]{2}{*}{ Second child male } & $-0.043^{* * *}$ & $0.032 * *$ & 0.011 & $-0.086 * * *$ & $0.079 * * *$ & 0.006 \\
\hline & $(0.016)$ & $(0.016)$ & $(0.008)$ & $(0.011)$ & $(0.012)$ & $(0.006)$ \\
\hline \multirow[t]{2}{*}{ Husband Son preference } & $0.035 * *$ & $-0.028 *$ & -0.007 & $0.045 * * *$ & $-0.041 * * *$ & -0.004 \\
\hline & $(0.016)$ & $(0.016)$ & $(0.008)$ & $(0.011)$ & $(0.011)$ & $(0.005)$ \\
\hline \multirow[t]{2}{*}{ Husband ideal number of children } & $0.033 * * *$ & $-0.039 * * *$ & $0.006^{*}$ & $0.032 * * *$ & $-0.032 * * *$ & 0.000 \\
\hline & $(0.007)$ & $(0.007)$ & $(0.003)$ & $(0.004)$ & $(0.005)$ & $(0.002)$ \\
\hline Observations & 5,303 & 5,303 & 5,303 & 10,506 & 10,506 & 10,506 \\
\hline \multicolumn{7}{|l|}{ Panel B } \\
\hline \multirow{2}{*}{ Son preference } & $-0.034 * *$ & $0.029 *$ & 0.005 & -0.002 & -0.008 & $0.009 *$ \\
\hline & $(0.016)$ & $(0.016)$ & $(0.007)$ & $(0.010)$ & $(0.011)$ & $(0.005)$ \\
\hline \multirow[t]{2}{*}{ Proportion of daughters } & $0.001^{* * *}$ & $-0.001 * * *$ & -0.000 & $0.002 * * *$ & $-0.001 * * *$ & $-0.000 * *$ \\
\hline & $(0.000)$ & $(0.000)$ & $(0.000)$ & $(0.000)$ & $(0.000)$ & $(0.000)$ \\
\hline \multirow[t]{2}{*}{ First child male } & $-0.079 * * *$ & $0.069 * * *$ & 0.010 & $-0.108 * * *$ & $0.098 * * *$ & $0.010^{*}$ \\
\hline & $(0.016)$ & $(0.016)$ & $(0.008)$ & $(0.011)$ & $(0.012)$ & $(0.006)$ \\
\hline \multirow[t]{2}{*}{ Second child male } & $-0.054 * * *$ & $0.039 * *$ & $0.014^{*}$ & $-0.094 * * *$ & $0.084 * * *$ & $0.010^{*}$ \\
\hline & $(0.015)$ & $(0.015)$ & $(0.007)$ & $(0.010)$ & $(0.011)$ & $(0.006)$ \\
\hline Husband Son preference & 0.016 & -0.013 & -0.003 & $0.027 * * *$ & $-0.023 * *$ & -0.004 \\
\hline
\end{tabular}




\begin{tabular}{lrrrrrr}
\hline & & NFHS 3 & & \multicolumn{2}{c}{ NFHS 4 } \\
Dependent Variable: Fertility Gap & Negative Gap & No Gap & Positive Gap & Negative Gap & No Gap & Positive Gap \\
\hline & $(0.016)$ & $(0.016)$ & $(0.007)$ & $(0.010)$ & $(0.011)$ & $(0.005)$ \\
Husband ideal number of children & $-0.168^{* * *}$ & $0.104^{* * *}$ & $0.064^{* * *}$ & $-0.141^{* * *}$ & $0.088^{* * *}$ & $0.053^{* * *}$ \\
& $(0.010)$ & $(0.010)$ & $(0.004)$ & $(0.006)$ & $(0.006)$ & $(0.003)$ \\
Difference in son preference & $0.051^{* * *}$ & $-0.065^{* * *}$ & $0.013^{* *}$ & $0.051^{* * *}$ & $-0.068^{* * *}$ & $0.017^{* * *}$ \\
& $(0.015)$ & $(0.015)$ & $(0.007)$ & $(0.010)$ & $(0.010)$ & $(0.005)$ \\
Difference in ideal no. of children & $0.238^{* * *}$ & $-0.163^{* * *}$ & $-0.074^{* * *}$ & $0.217^{* * *}$ & $-0.148^{* * *}$ & $-0.069^{* * *}$ \\
& $(0.008)$ & $(0.008)$ & $(0.004)$ & $(0.005)$ & $(0.005)$ & $(0.003)$ \\
\hline Observations & 5,303 & 5,303 & 5,303 & 10,506 & 10,506 & 10,506 \\
\hline
\end{tabular}

Notes: Fertility gap defined as difference between ideal and actual number of children. Standard errors in parentheses. Multinomial logit estimations including controls for husband's age, education and employment status, woman's age, education employment status, media exposure and age at first birth, marital years, contraception use, rural location, region size, religion and social group (Scheduled Tribe/Class) of the household. ${ }^{* * *} \mathrm{p}<0.01,{ }^{* *} \mathrm{p}<0.05,{ }^{*} \mathrm{p}<0.1$ 
Table 5: Number of children (OLS regression)

\begin{tabular}{|c|c|c|c|c|}
\hline $\begin{array}{l}\text { Dependent Variable: } \\
\text { (actual) number of children }\end{array}$ & $\begin{array}{c}\text { NFHS } 3 \\
(1)\end{array}$ & $\begin{array}{c}\text { NFHS } 4 \\
(2)\end{array}$ & $\begin{array}{c}\text { NFHS } 3 \\
(3)\end{array}$ & $\begin{array}{c}\text { NFHS } 4 \\
(4)\end{array}$ \\
\hline Ideal number of children & $\begin{array}{r}0.535^{* * * *} \\
(0.023)\end{array}$ & $\begin{array}{r}0.584^{* * *} \\
(0.013)\end{array}$ & (omitted) & (omitted) \\
\hline Son preference & $\begin{array}{r}0.054 \\
(0.043)\end{array}$ & $\begin{array}{r}0.060 * * \\
(0.025)\end{array}$ & $\begin{array}{r}0.065 \\
(0.040)\end{array}$ & $\begin{array}{r}0.086 * * * \\
(0.024)\end{array}$ \\
\hline Proportion of daughters & $\begin{array}{r}0.008 * * * \\
(0.001)\end{array}$ & $\begin{array}{r}0.010 * * * \\
(0.000)\end{array}$ & $\begin{array}{r}0.004^{* * *} \\
(0.001)\end{array}$ & $\begin{array}{r}0.005^{* * *} \\
(0.001)\end{array}$ \\
\hline First child male & & & $\begin{array}{r}-0.218 * * * \\
(0.042)\end{array}$ & $\begin{array}{r}-0.298 * * * \\
(0.027)\end{array}$ \\
\hline Second child male & & & $\begin{array}{r}-0.202 * * * \\
(0.040)\end{array}$ & $\begin{array}{r}-0.237 * * * \\
(0.026)\end{array}$ \\
\hline Husband Son preference & & & $\begin{array}{r}0.120 * * * \\
(0.039)\end{array}$ & $\begin{array}{r}0.055 * * \\
(0.024)\end{array}$ \\
\hline Husband ideal number of children & & & $\begin{array}{r}0.472^{* * *} \\
(0.023)\end{array}$ & $\begin{array}{r}0.534 * * * \\
(0.013)\end{array}$ \\
\hline Difference in ideal number of children & $\begin{array}{r}0.248 * * * \\
(0.017)\end{array}$ & $\begin{array}{r}0.269 * * * \\
(0.010)\end{array}$ & $\begin{array}{r}-0.259 * * * \\
(0.019)\end{array}$ & $\begin{array}{r}-0.286^{* * * *} \\
(0.011)\end{array}$ \\
\hline Difference in son preference & $\begin{array}{r}0.047 \\
(0.037) \\
\end{array}$ & $\begin{array}{r}0.063 * * * \\
(0.023)\end{array}$ & & \\
\hline Observations & 5,665 & 11,304 & 5,303 & 10,506 \\
\hline R square & 0.502 & 0.529 & 0.488 & 0.511 \\
\hline
\end{tabular}

Notes: Standard errors in parentheses. OLS estimations including controls for husband's age, education and employment status, woman's age, education employment status, media exposure and age at first birth, marital years, contraception use, rural location, region size, religion and social group (Scheduled Tribe/Class) of the household. ${ }^{* * *} \mathrm{p}<0.01,{ }^{* *} \mathrm{p}<0.05$, ${ }^{*} \mathrm{p}<0.1$ 
Figure 1: Fertility gap in India 2005/06 - 2015/16

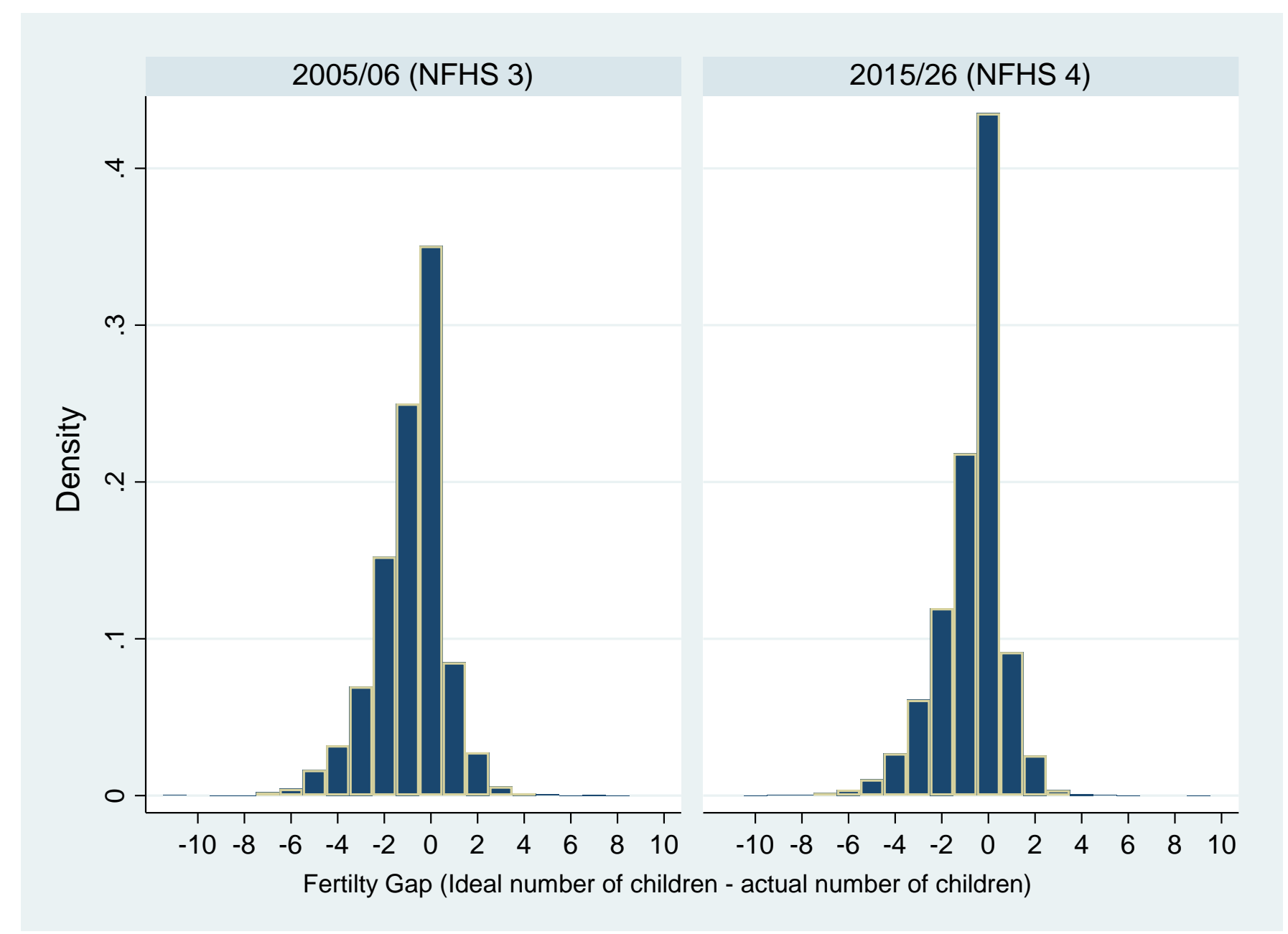

Notes: Fertility gap defined as difference between ideal and actual number of children. Using NFHS 3 and NFHS 4 data. Sample restricted to women aged 40 and above. 
Figure 2: Son preference and fertility

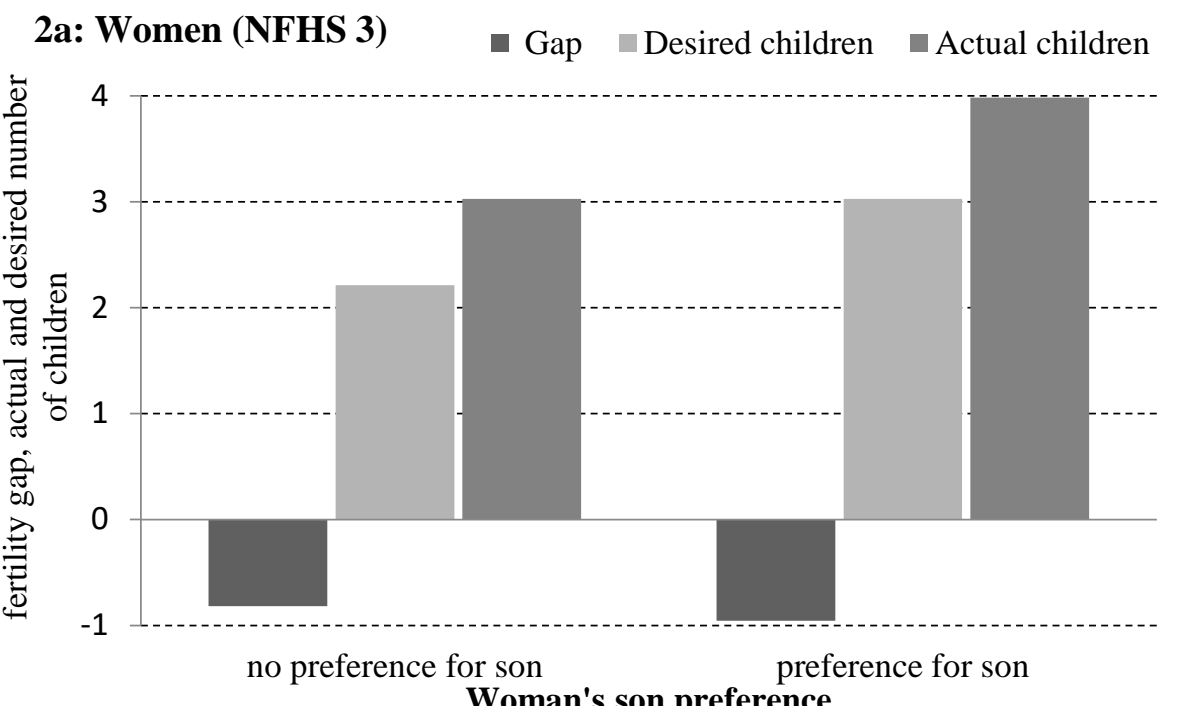

\section{2c: Husband (NFHS 3) — Gap $\quad$ - Desired children $\quad$ actual children}

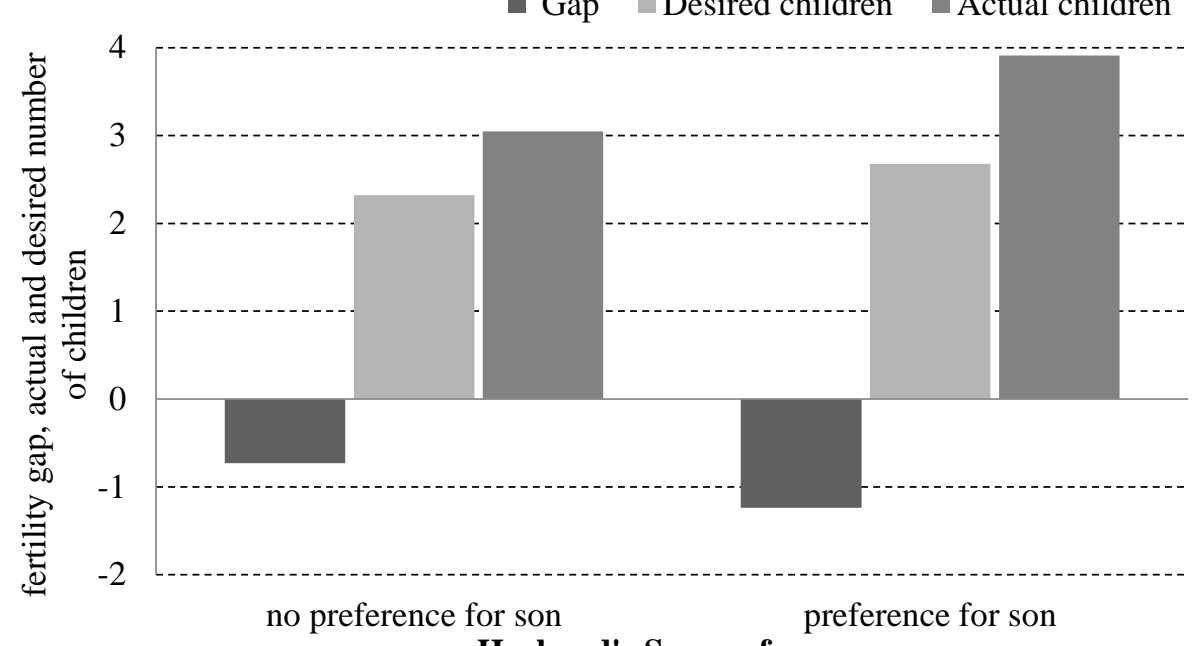

Husband's Son preference

\section{2b: Women (NFHS 4)}

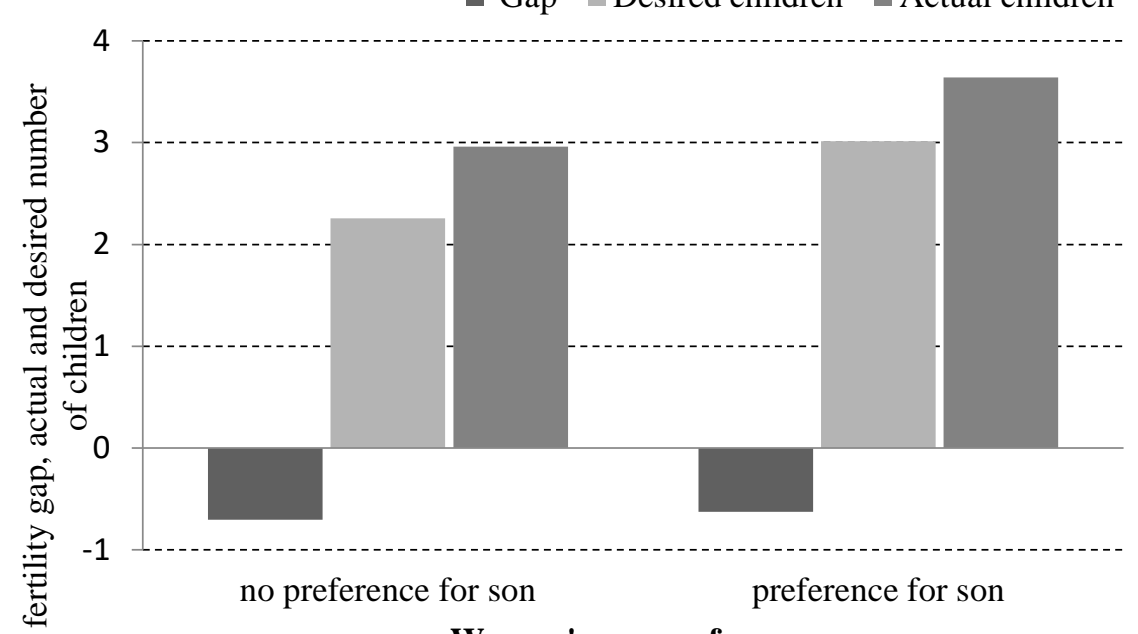

Woman's son preference

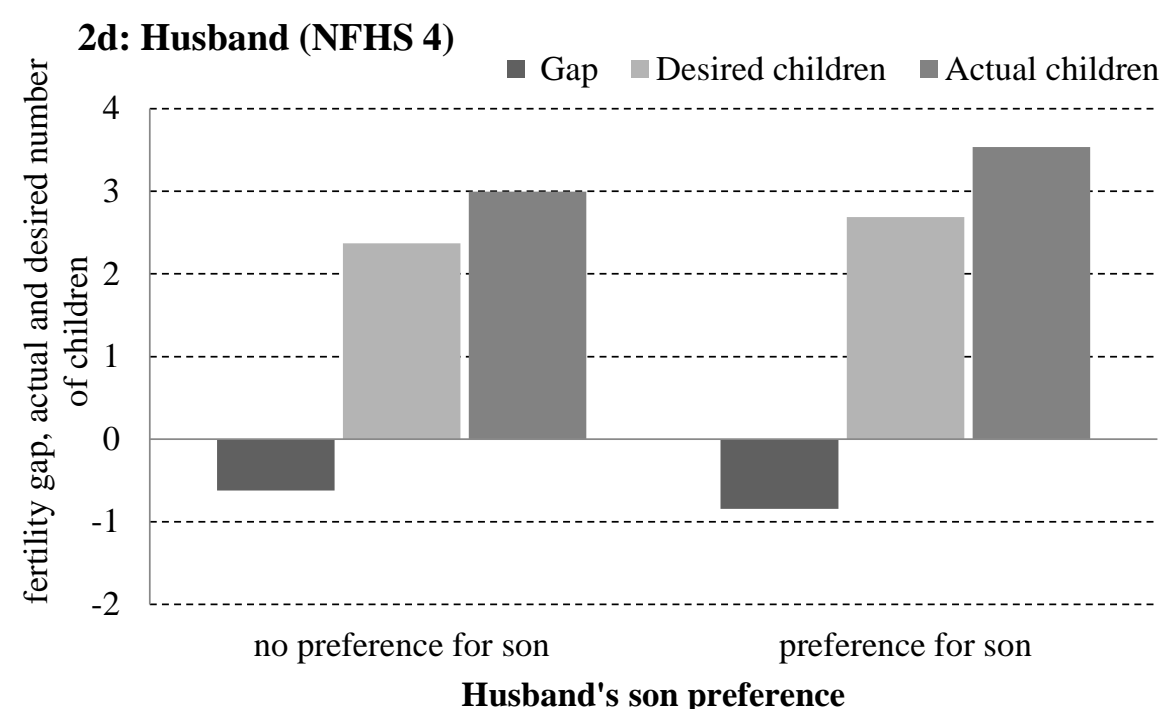


Figure 3: Daughters and fertility

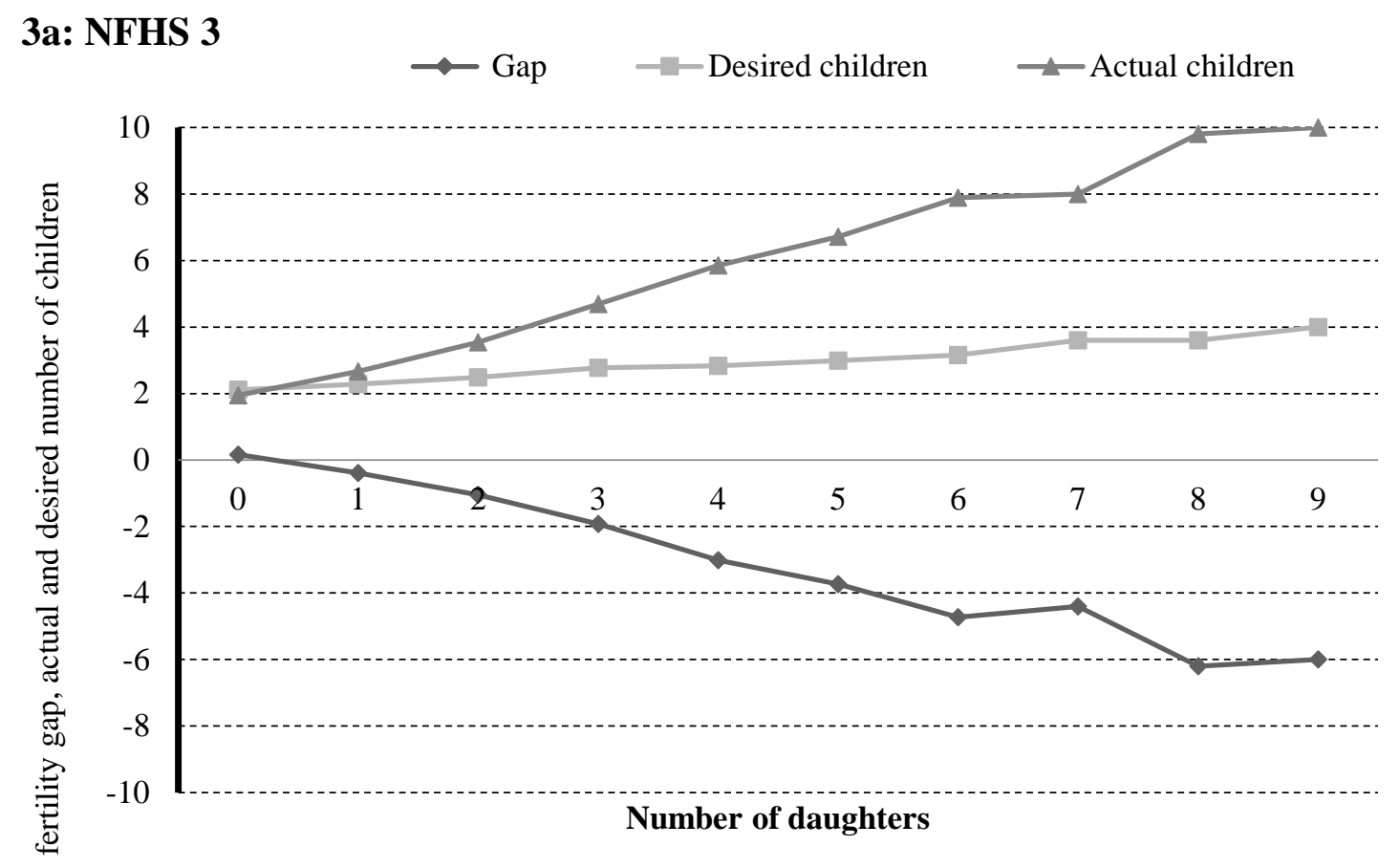

3b: NFHS 4
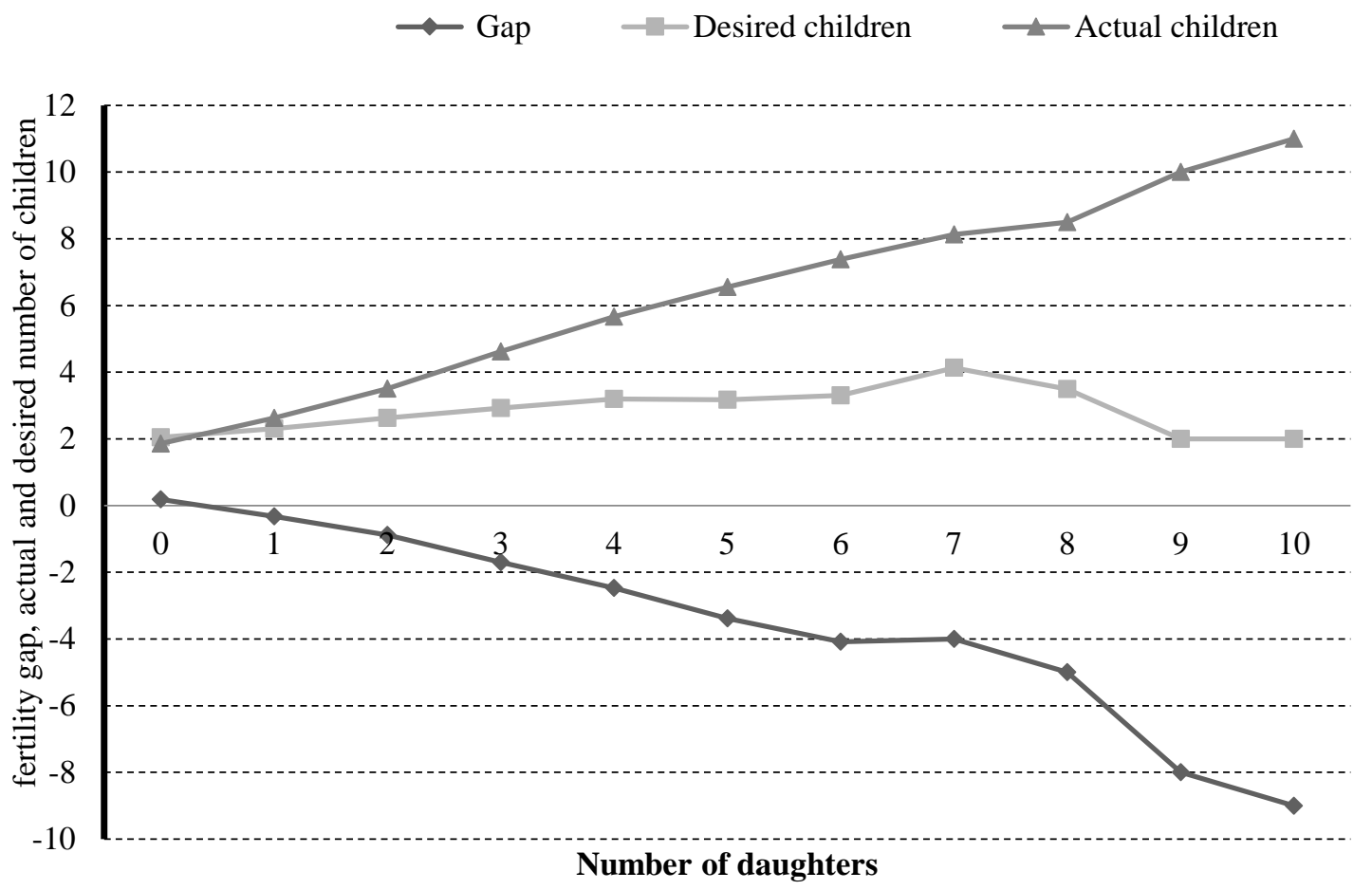

Notes: Fertility gap defined as difference between ideal and actual number of children. Using NFHS 3 and NFHS 4 data. Sample restricted to women aged 40 and above. 


\section{Appendix}

Table A1: Definition of Variables employed in analysis

\begin{tabular}{|c|c|}
\hline Variable & Description \\
\hline $\begin{array}{l}\text { Fertility Gap (dependent } \\
\text { variable) }\end{array}$ & $\begin{array}{l}\text { Measured as difference between ideal number of children } \\
\text { and actual number of children (Ideal - Actual). Actual } \\
\text { number of children includes current pregnancies and living } \\
\text { children only. }\end{array}$ \\
\hline Son preference & $\begin{array}{l}\text { Binary variable, taking value } 1 \text { if woman's ideal number of } \\
\text { Number of daughters in total living children (in \%), }\end{array}$ \\
\hline Proportion of daughters & calculated as $\left(\left(\frac{\text { number of daughters }}{\text { Living children }}\right) \times 100\right)$ \\
\hline First child male & $\begin{array}{l}\text { Binary variable, taking value } 1 \text { if first child male, } 0 \text { if } \\
\text { female }\end{array}$ \\
\hline Second child male & Binary variable, taking value 1 if first child male, 0 if \\
\hline Husband son preference & $\begin{array}{l}\text { Binary variable, taking value } 1 \text { if husband's ideal number of } \\
\text { boys>ideal number of girls, } 0 \text { otherwise }\end{array}$ \\
\hline Husband ideal number of & Husband’s ideal family size \\
\hline Difference in son preference & $\begin{array}{l}\text { Binary variable, taking value } 1 \text { if husband and wife son } \\
\text { preference differ, } 0 \text { otherwise }\end{array}$ \\
\hline $\begin{array}{l}\text { Difference in ideal no of } \\
\text { children }\end{array}$ & $\begin{array}{l}\text { Measured as difference between husband and wife's ideal } \\
\text { number of children (husband'ideal - wife'sideal). }\end{array}$ \\
\hline Never used contraception & Binary variable, taking value 1 if never used contraception, \\
\hline Woman: Education (yrs) & Education years of woman \\
\hline Woman: Employed & Binary variable, taking value 1 if currently working, 0 \\
\hline Woman: Media exposure & $\begin{array}{l}\text { Combines three modes of media; 'reading newspaper' } \\
\text { 'watching TV' and 'listening radio'. This usage of media is } \\
\text { converted into binary variables, taking value } 1 \text { if woman } \\
\text { reads/watches/listens to newspaper/TV/radio at least once a } \\
\text { week, } 0 \text { otherwise. Media exposure is then calculated as } \\
\text { sum of these three dummy variables and converted into \%. } \\
(\text { (reading dummy }+ \text { watching dummy }+ \\
\text { listening dummy) } \times 100 / 3)\end{array}$ \\
\hline Woman: Age (yrs) & Age of woman in years \\
\hline Woman: Age at first birth & Age of woman at the time of first child's birth in years \\
\hline Woman: Married (yrs) & Number of marital years for woman \\
\hline Husband: Age (yrs) & Age of husband in years \\
\hline Husband: Education (yrs) & Education years of husband \\
\hline Husband: Employed & Binary variable, taking value 1 if husband is employed, 0 \\
\hline Social group & $\begin{array}{l}\text { Binary variable, taking value } 1 \text { if household belongs to } \\
\text { SC/ST group, } 0 \text { otherwise }\end{array}$ \\
\hline Hindu & $\begin{array}{l}\text { Binary variable, taking value } 1 \text { if religion of household head } \\
\text { is 'hindu', } 0 \text { otherwise }\end{array}$ \\
\hline Household size & Number of household members \\
\hline
\end{tabular}




\begin{tabular}{ll}
\hline Economic status & Binary variable, taking value 1 if household belongs \\
& medium to rich wealth status, 0 otherwise. The underlying \\
& variable is wealth index which takes values 1 to 5 with 1 \\
Region: North & Binary variable, taking value 1 if household is located in \\
& northern region, 0 otherwise. Northern region includes \\
& states of Gujarat, Rajasthan, Uttar Pradesh, Madhya \\
& Pradesh, Punjab, Haryana, Himachal Pradesh and Delhi. \\
Binary variable, taking value 1 if household is located in \\
Region: South & Southern region, 0 otherwise. Southern region includes \\
& states of Andhra Pradesh, Karnataka, Kerala, Maharashtra \\
Reference region is 'East'. Eastern region includes states of Assam, Bihar, Orissa and \\
Rural \\
Binary variable, taking value 1 if household is located in \\
rural area, 0 if urban area.
\end{tabular}


Table A2: Full results for fertility gap: Average Marginal effects from multinominal estimations.

\begin{tabular}{|c|c|c|c|c|c|c|}
\hline \multirow[b]{2}{*}{ Dependent Variable: Fertility Gap } & \multicolumn{3}{|c|}{ NFHS 3} & \multicolumn{3}{|c|}{ NFHS 4} \\
\hline & Negative Gap & No Gap & Positive Gap & Negative Gap & No Gap & Positive Gap \\
\hline \multirow[t]{2}{*}{ Son preference } & $-0.0336 * *$ & $0.0286 *$ & 0.0049 & -0.0017 & -0.0078 & $0.0095^{*}$ \\
\hline & $(0.0161)$ & $(0.0165)$ & $(0.0071)$ & $(0.0102)$ & $(0.0107)$ & $(0.0050)$ \\
\hline \multirow[t]{2}{*}{ Proportion of daughters } & $0.0011 * * *$ & $-0.0011^{* * *}$ & -0.0001 & $0.0017 * * *$ & $-0.0013^{* * *}$ & $-0.0003 * *$ \\
\hline & $(0.0003)$ & $(0.0003)$ & $(0.0002)$ & $(0.0002)$ & $(0.0003)$ & $(0.0001)$ \\
\hline \multirow[t]{2}{*}{ First child male } & $-0.0791 * * *$ & $0.0692 * * *$ & 0.0099 & $-0.1078 * * *$ & $0.0976 * * *$ & $0.0102 *$ \\
\hline & $(0.0158)$ & $(0.0164)$ & $(0.0080)$ & $(0.0110)$ & $(0.0117)$ & $(0.0060)$ \\
\hline \multirow[t]{2}{*}{ Second child male } & $-0.0536 * * *$ & $0.0390 * *$ & $0.0145 *$ & $-0.0937 * * *$ & $0.0836 * * *$ & $0.0100 *$ \\
\hline & $(0.0150)$ & $(0.0154)$ & $(0.0075)$ & $(0.0105)$ & $(0.0112)$ & $(0.0056)$ \\
\hline \multirow[t]{2}{*}{ Husband Son Preference } & 0.0164 & -0.0129 & -0.0035 & $0.0268 * * *$ & $-0.0227 * *$ & -0.0041 \\
\hline & $(0.0158)$ & $(0.0163)$ & $(0.0073)$ & $(0.0101)$ & $(0.0107)$ & $(0.0051)$ \\
\hline \multirow[t]{2}{*}{ Husband Ideal number of children } & $-0.1682 * * *$ & $0.1038 * * *$ & $0.0644 * * *$ & $-0.1411 * * *$ & $0.0880 * * *$ & $0.0531^{* * *}$ \\
\hline & $(0.0097)$ & $(0.0099)$ & $(0.0044)$ & $(0.0057)$ & $(0.0060)$ & $(0.0029)$ \\
\hline \multirow[t]{2}{*}{ Difference in son preference } & $0.0514 * * *$ & $-0.0649 * * *$ & $0.0135^{* *}$ & $0.0506 * * *$ & $-0.0680 * * *$ & $0.0174 * * *$ \\
\hline & $(0.0149)$ & $(0.0153)$ & $(0.0069)$ & $(0.0097)$ & $(0.0102)$ & $(0.0049)$ \\
\hline \multirow[t]{2}{*}{ Difference in ideal no of children } & $0.2379 * * *$ & $-0.1634 * * *$ & $-0.0745 * * *$ & $0.2172 * * *$ & $-0.1478 * * *$ & $-0.0695 * * *$ \\
\hline & $(0.0078)$ & $(0.0081)$ & $(0.0038)$ & $(0.0047)$ & $(0.0051)$ & $(0.0029)$ \\
\hline \multirow[t]{2}{*}{ Never used contraception } & -0.0078 & -0.0226 & $0.0304 * * *$ & -0.0098 & -0.0082 & $0.0180 * * *$ \\
\hline & $(0.0170)$ & $(0.0174)$ & $(0.0073)$ & $(0.0102)$ & $(0.0107)$ & $(0.0050)$ \\
\hline \multirow[t]{2}{*}{ Woman: Education (yrs) } & $-0.0131 * * *$ & $0.0122 * * *$ & 0.0010 & $-0.0103 * * *$ & $0.0095 * * *$ & 0.0008 \\
\hline & $(0.0017)$ & $(0.0017)$ & $(0.0010)$ & $(0.0012)$ & $(0.0013)$ & $(0.0007)$ \\
\hline \multirow[t]{2}{*}{ Woman: Employed } & $-0.0230 *$ & 0.0183 & 0.0047 & -0.0012 & -0.0006 & 0.0018 \\
\hline & $(0.0124)$ & $(0.0127)$ & $(0.0064)$ & $(0.0091)$ & (0.0097) & $(0.0049)$ \\
\hline Woman: Media exposure & $-0.0007 * * *$ & $0.0007 * * *$ & 0.0000 & $-0.0010 * * *$ & $0.0010 * * *$ & 0.0000 \\
\hline
\end{tabular}




\begin{tabular}{|c|c|c|c|c|c|c|}
\hline \multirow[b]{2}{*}{ Dependent Variable: Fertility Gap } & \multicolumn{3}{|c|}{ NFHS 3} & \multicolumn{3}{|c|}{ NFHS 4} \\
\hline & Negative Gap & No Gap & Positive Gap & Negative Gap & No Gap & Positive Gap \\
\hline \multirow{3}{*}{ Woman: Age (yrs) } & $(0.0002)$ & $(0.0002)$ & $(0.0001)$ & $(0.0002)$ & $(0.0002)$ & $(0.0001)$ \\
\hline & $0.0121 * * *$ & $-0.0076^{* *}$ & $-0.0045^{* * *}$ & 0.0039 & -0.0002 & $-0.0038 * * *$ \\
\hline & $(0.0036)$ & $(0.0037)$ & $(0.0017)$ & $(0.0024)$ & $(0.0026)$ & $(0.0013)$ \\
\hline \multirow[t]{2}{*}{ Woman: Age at first birth (yrs) } & $-0.0227 * * *$ & $0.0171^{* * *}$ & $0.0057 * * *$ & $-0.0149 * * *$ & $0.0100 * * *$ & $0.0049 * * *$ \\
\hline & $(0.0026)$ & $(0.0027)$ & $(0.0012)$ & $(0.0017)$ & $(0.0018)$ & $(0.0009)$ \\
\hline \multirow[t]{2}{*}{ Woman: Married (yrs) } & 0.0005 & -0.0036 & $0.0031^{* *}$ & 0.0026 & $-0.0045^{* *}$ & $0.0019 * *$ \\
\hline & $(0.0027)$ & $(0.0027)$ & $(0.0013)$ & $(0.0017)$ & $(0.0018)$ & $(0.0009)$ \\
\hline \multirow[t]{2}{*}{ Husband: Age (yrs) } & -0.0017 & 0.0022 & -0.0006 & -0.0014 & 0.0010 & 0.0004 \\
\hline & $(0.0020)$ & $(0.0020)$ & $(0.0010)$ & $(0.0014)$ & $(0.0014)$ & $(0.0007)$ \\
\hline \multirow[t]{2}{*}{ Husband: Education (yrs) } & -0.0013 & 0.0010 & 0.0003 & -0.0012 & $0.0014^{*}$ & -0.0002 \\
\hline & $(0.0009)$ & $(0.0010)$ & $(0.0005)$ & $(0.0008)$ & $(0.0008)$ & $(0.0004)$ \\
\hline \multirow[t]{2}{*}{ Husband: Employed } & 0.0552 & -0.0262 & $-0.0289 *$ & -0.0315 & 0.0197 & 0.0118 \\
\hline & $(0.0388)$ & $(0.0388)$ & $(0.0164)$ & $(0.0219)$ & $(0.0236)$ & $(0.0133)$ \\
\hline \multirow[t]{2}{*}{ Social group } & $0.0298 * *$ & $-0.0395 * * *$ & 0.0097 & 0.0104 & $-0.0197 * *$ & $0.0094 *$ \\
\hline & $(0.0148)$ & $(0.0152)$ & $(0.0070)$ & $(0.0092)$ & $(0.0097)$ & $(0.0049)$ \\
\hline \multirow[t]{2}{*}{ Hindu } & $-0.0559 * * *$ & $0.0491^{* * *}$ & 0.0068 & $-0.0598 * * *$ & $0.0504 * * *$ & 0.0094 \\
\hline & $(0.0159)$ & $(0.0163)$ & $(0.0085)$ & $(0.0114)$ & $(0.0121)$ & $(0.0063)$ \\
\hline \multirow[t]{2}{*}{ Household size } & $0.0575 * * *$ & $-0.0342 * * *$ & $-0.0233 * * *$ & $0.0578 * * *$ & $-0.0398 * * *$ & $-0.0179 * * *$ \\
\hline & $(0.0029)$ & $(0.0031)$ & $(0.0020)$ & $(0.0020)$ & $(0.0022)$ & $(0.0014)$ \\
\hline \multirow[t]{2}{*}{ Economic status } & $-0.0490 * * *$ & $0.0467 * * *$ & 0.0024 & $-0.0754 * * *$ & $0.0640 * * *$ & $0.0114^{*}$ \\
\hline & (0.0172) & (0.0177) & $(0.0080)$ & (0.0109) & (0.0116) & $(0.0059)$ \\
\hline \multirow[t]{2}{*}{ Region: North } & $0.0806 * * *$ & $-0.0628 * * *$ & $-0.0178 *$ & $0.0308 * * *$ & $-0.0335 * * *$ & 0.0027 \\
\hline & (0.0207) & (0.0213) & $(0.0102)$ & (0.0109) & (0.0116) & $(0.0059)$ \\
\hline \multirow[t]{2}{*}{ Region: South } & -0.0229 & 0.0214 & 0.0014 & $-0.1120 * * *$ & $0.0876 * * *$ & $0.0244 * * *$ \\
\hline & $(0.0205)$ & $(0.0210)$ & $(0.0100)$ & $(0.0136)$ & $(0.0142)$ & (0.0071) \\
\hline
\end{tabular}




\begin{tabular}{lrrrrrr}
\hline & & NFHS 3 & & \multicolumn{2}{c}{ NFHS 4 } \\
Dependent Variable: Fertility Gap & Negative Gap & No Gap & Positive Gap & Negative Gap & No Gap & Positive Gap \\
\hline Rural & $-0.0421^{* * *}$ & $0.0270^{*}$ & $0.0152^{* *}$ & -0.0131 & 0.0062 & 0.0069 \\
& $(0.0136)$ & $(0.0140)$ & $(0.0073)$ & $(0.0099)$ & $(0.0104)$ & $(0.0057)$ \\
\hline Observations & 5,303 & 5,303 & 5,303 & 10,506 & 10,506 & 10,506 \\
\hline
\end{tabular}

Notes: Fertility gap defined as difference between ideal and actual number of children. Full set of results corresponding to specification reported in Panel B in Table 4. Standard errors in parentheses. Multinomial logit estimations. ${ }^{* * *} \mathrm{p}<0.01,{ }^{* *} \mathrm{p}<0.05$, $* \mathrm{p}<0.1$ 
Table A3: Full results for fertility gap: OLS estimations.

\begin{tabular}{|c|c|c|}
\hline Dependent Variable: Fertility Gap & NFHS 3 & NFHS 4 \\
\hline \multirow[t]{2}{*}{ Son preference } & -0.0604 & $-0.0658 * * *$ \\
\hline & $(0.0425)$ & $(0.0252)$ \\
\hline \multirow[t]{2}{*}{ Proportion of daughters } & $-0.0045^{* * *}$ & $-0.0049 * * *$ \\
\hline & $(0.0009)$ & $(0.0006)$ \\
\hline \multirow[t]{2}{*}{ First child male } & $0.2177 * * *$ & $0.2977 * * *$ \\
\hline & $(0.0423)$ & $(0.0274)$ \\
\hline \multirow[t]{2}{*}{ Second child male } & $0.2016 * * *$ & $0.2374 * * *$ \\
\hline & $(0.0399)$ & $(0.0261)$ \\
\hline \multirow[t]{2}{*}{ Husband Son Preference } & $-0.1153 * * *$ & -0.0334 \\
\hline & $(0.0416)$ & $(0.0248)$ \\
\hline \multirow[t]{2}{*}{ Husband Ideal number of children } & $0.5286 * * *$ & $0.4664 * * *$ \\
\hline & $(0.0235)$ & $(0.0129)$ \\
\hline \multirow[t]{2}{*}{ Difference in son preference } & -0.0128 & $-0.0684^{* * *}$ \\
\hline & $(0.0397)$ & (0.0239) \\
\hline \multirow[t]{2}{*}{ Difference in ideal no of children } & $-0.7408 * * *$ & $-0.7138 * * *$ \\
\hline & $(0.0192)$ & $(0.0106)$ \\
\hline \multirow[t]{2}{*}{ Never used contraception } & $-0.1351 * * *$ & $-0.0817^{* * *}$ \\
\hline & $(0.0449)$ & $(0.0246)$ \\
\hline \multirow[t]{2}{*}{ Woman: Education (yrs) } & $0.0403 * * *$ & $0.0282 * * *$ \\
\hline & $(0.0047)$ & $(0.0030)$ \\
\hline \multirow[t]{2}{*}{ Woman: Employed } & 0.0105 & 0.0233 \\
\hline & $(0.0335)$ & $(0.0223)$ \\
\hline \multirow[t]{2}{*}{ Woman: Media exposure } & $0.0023 * * *$ & $0.0028 * * *$ \\
\hline & $(0.0006)$ & $(0.0005)$ \\
\hline \multirow[t]{2}{*}{ Woman: Age (yrs) } & $-0.0549 * * *$ & $-0.0307 * * *$ \\
\hline & $(0.0099)$ & (0.0059) \\
\hline \multirow[t]{2}{*}{ Woman: Age at first birth (yrs) } & $0.0735^{* * *}$ & $0.0449 * * *$ \\
\hline & $(0.0072)$ & $(0.0042)$ \\
\hline \multirow[t]{2}{*}{ Woman: Married (yrs) } & 0.0085 & -0.0011 \\
\hline & $(0.0074)$ & $(0.0041)$ \\
\hline \multirow[t]{2}{*}{ Husband: Age (yrs) } & $0.0162 * * *$ & $0.0074 * *$ \\
\hline & $(0.0054)$ & $(0.0032)$ \\
\hline \multirow[t]{2}{*}{ Husband: Education (yrs) } & 0.0030 & $0.0064 * * *$ \\
\hline & $(0.0026)$ & $(0.0019)$ \\
\hline \multirow[t]{2}{*}{ Husband: Employed } & -0.1034 & 0.0768 \\
\hline & $(0.1028)$ & $(0.0536)$ \\
\hline \multirow[t]{2}{*}{ Social group } & $-0.0660 *$ & 0.0164 \\
\hline & $(0.0393)$ & $(0.0226)$ \\
\hline \multirow[t]{2}{*}{ Hindu } & $0.4242 * * *$ & $0.2588 * * *$ \\
\hline & $(0.0424)$ & $(0.0279)$ \\
\hline
\end{tabular}




\begin{tabular}{lrr}
\hline Dependent Variable: Fertility Gap & \multicolumn{1}{c}{ NFHS 3 } & \multicolumn{1}{c}{ NFHS 4 } \\
\hline Household size & $-0.1914^{* * *}$ & $-0.1879^{* * *}$ \\
& $(0.0065)$ & $(0.0046)$ \\
Economic status & $0.2461^{* * *}$ & $0.3195^{* * *}$ \\
& $(0.0457)$ & $(0.0269)$ \\
Region: North & $-0.2574^{* * *}$ & -0.0384 \\
& $(0.0555)$ & $(0.0270)$ \\
Region: South & $0.1394^{* *}$ & $0.2445^{* * *}$ \\
& $(0.0555)$ & $(0.0333)$ \\
Rural & $0.1496 * * *$ & $0.0666^{* * *}$ \\
& $(0.0371)$ & $(0.0243)$ \\
\hline Observations & 5,303 & 10,506 \\
\hline R squared & 0.4083 & 0.4381 \\
\hline
\end{tabular}

Notes: Fertility gap defined as difference between ideal and actual number of children. Full set of results corresponding to specification reported in Panel B in Table 4. Coefficients estimated using OLS regressions. Regressions includes constant term. Standard errors in parentheses ${ }^{* * *} \mathrm{p}<0.01$, ${ }^{* *} \mathrm{p}<0.05$, $* \mathrm{p}<0.1$ 
Table A4: Full results for fertility gap: Average Marginal effects from multinominal estimations. Pooled NFHS 3 and NFHS 4 sample

\begin{tabular}{|c|c|c|c|}
\hline Dependent Variable: Fertility Gap & Negative Gap & No Gap & Positive Gap \\
\hline \multirow[t]{2}{*}{ Son preference } & -0.0109 & 0.0026 & $0.0083^{* *}$ \\
\hline & $(0.0087)$ & $(0.0091)$ & $(0.0041)$ \\
\hline \multirow[t]{2}{*}{ Proportion of daughters } & $0.0014 * * *$ & $-0.0012 * * *$ & $-0.0002 * *$ \\
\hline & $(0.0002)$ & $(0.0002)$ & $(0.0001)$ \\
\hline \multirow[t]{2}{*}{ First child male } & $-0.0994 * * *$ & $0.0893 * * *$ & $0.0101 * *$ \\
\hline & $(0.0091)$ & $(0.0096)$ & $(0.0048)$ \\
\hline \multirow[t]{2}{*}{ Second child male } & $-0.0827 * * *$ & $0.0704 * * *$ & $0.0124 * * *$ \\
\hline & $(0.0087)$ & $(0.0091)$ & $(0.0045)$ \\
\hline \multirow[t]{2}{*}{ Husband Son Preference } & $0.0221 * *$ & $-0.0183^{* *}$ & -0.0037 \\
\hline & $(0.0086)$ & $(0.0090)$ & $(0.0042)$ \\
\hline \multirow[t]{2}{*}{ Husband Ideal number of children } & $-0.1481^{* * *}$ & $0.0921^{* * *}$ & $0.0560 * * *$ \\
\hline & $(0.0050)$ & $(0.0052)$ & $(0.0024)$ \\
\hline \multirow[t]{2}{*}{ Difference in son preference } & $0.0495 * * *$ & $-0.0665 * * *$ & $0.0170 * * *$ \\
\hline & $(0.0082)$ & $(0.0085)$ & $(0.0040)$ \\
\hline \multirow[t]{2}{*}{ Difference in ideal no of children } & $0.2228 * * *$ & $-0.1519 * * *$ & $-0.0709 * * *$ \\
\hline & $(0.0041)$ & $(0.0044)$ & $(0.0023)$ \\
\hline \multirow[t]{2}{*}{ Never used contraception } & $-0.0158 *$ & -0.0059 & $0.0217 * * *$ \\
\hline & $(0.0088)$ & $(0.0092)$ & $(0.0041)$ \\
\hline \multirow[t]{2}{*}{ Woman: Education (yrs) } & $-0.0122 * * *$ & $0.0114 * * *$ & 0.0008 \\
\hline & $(0.0010)$ & $(0.0010)$ & $(0.0005)$ \\
\hline \multirow[t]{2}{*}{ Woman: Employed } & 0.0006 & -0.0053 & 0.0047 \\
\hline & $(0.0074)$ & $(0.0077)$ & $(0.0039)$ \\
\hline \multirow[t]{2}{*}{ Woman: Media exposure } & $-0.0006 * * *$ & $0.0006^{* * *}$ & -0.0000 \\
\hline & $(0.0002)$ & $(0.0002)$ & $(0.0001)$ \\
\hline \multirow[t]{2}{*}{ Woman: Age (yrs) } & $0.0052 * *$ & -0.0009 & $-0.0043^{* * *}$ \\
\hline & $(0.0020)$ & $(0.0021)$ & $(0.0010)$ \\
\hline \multirow[t]{2}{*}{ Woman: Age at first birth (yrs) } & $-0.0174 * * *$ & $0.0122^{* * *}$ & $0.0053 * * *$ \\
\hline & $(0.0015)$ & $(0.0015)$ & $(0.0007)$ \\
\hline \multirow[t]{2}{*}{ Woman: Married (yrs) } & $0.0028 *$ & $-0.0053 * * *$ & $0.0025 * * *$ \\
\hline & $(0.0015)$ & $(0.0015)$ & $(0.0007)$ \\
\hline \multirow[t]{2}{*}{ Husband: Age (yrs) } & -0.0015 & 0.0013 & 0.0001 \\
\hline & $(0.0011)$ & $(0.0012)$ & $(0.0006)$ \\
\hline \multirow[t]{2}{*}{ Husband: Education (yrs) } & -0.0008 & 0.0009 & -0.0001 \\
\hline & $(0.0006)$ & $(0.0006)$ & $(0.0003)$ \\
\hline \multirow[t]{2}{*}{ Husband: Employed } & -0.0000 & 0.0003 & -0.0003 \\
\hline & $(0.0194)$ & $(0.0202)$ & $(0.0103)$ \\
\hline \multirow[t]{2}{*}{ Social group } & 0.0083 & $-0.0177 * *$ & $0.0094 * *$ \\
\hline & $(0.0079)$ & $(0.0082)$ & $(0.0040)$ \\
\hline Hindu & $-0.0579 * * *$ & $0.0486^{* * *}$ & $0.0093 *$ \\
\hline
\end{tabular}




\begin{tabular}{lrrr}
\hline Dependent Variable: Fertility Gap & Negative Gap & \multicolumn{1}{c}{ No Gap } & Positive Gap \\
\hline \multirow{3}{*}{ Household size } & $(0.0094)$ & $(0.0098)$ & $(0.0051)$ \\
& $0.0604^{* * *}$ & $-0.0405^{* * *}$ & $-0.0199^{* * *}$ \\
Economic status & $(0.0016)$ & $(0.0018)$ & $(0.0012)$ \\
& $-0.0729 * * *$ & $0.0626^{* * *}$ & $0.0102^{* *}$ \\
Region: North & $(0.0092)$ & $(0.0097)$ & $(0.0047)$ \\
& $0.0363^{* * *}$ & $-0.0369^{* * *}$ & 0.0007 \\
Region: South & $(0.0098)$ & $(0.0102)$ & $(0.0051)$ \\
& $-0.0522^{* * *}$ & $0.0312^{* * *}$ & $0.0210^{* * *}$ \\
Rural & $(0.0109)$ & $(0.0114)$ & $(0.0057)$ \\
& $-0.0442^{* * *}$ & $0.0345^{* * *}$ & $0.0097 * *$ \\
Observations & $(0.0079)$ & $(0.0083)$ & $(0.0045)$ \\
\hline
\end{tabular}

Notes: Fertility gap defined as difference between ideal and actual number of children. Full set of results corresponding to specification reported in Panel B in Table 4. Using pooled NFHS 3 and NFHS 4 sample. Multinominal estimations. Standard errors in parentheses $* * * \mathrm{p}<0.01$, ${ }^{* *} \mathrm{p}<0.05,{ }^{*} \mathrm{p}<0.1$ 
Table A5: Fertility and son preference by state

\begin{tabular}{|c|c|c|c|c|c|c|c|c|c|}
\hline \multirow[b]{3}{*}{ State } & \multicolumn{4}{|c|}{ NFHS 3} & & \multicolumn{4}{|c|}{ MFHS 4} \\
\hline & \multirow[b]{2}{*}{ Sample } & \multicolumn{2}{|c|}{ No of children } & \multirow[b]{2}{*}{ Son preference } & & \multirow[b]{2}{*}{ Sample } & \multicolumn{2}{|c|}{ No of children } & \multirow[b]{2}{*}{ Son preference } \\
\hline & & Ideal & Actual & & & & Ideal & Actual & \\
\hline & $\%$ & Mean & Mean & Mean & & $\%$ & Mean & Mean & Mean \\
\hline Andhra Pradesh^^ & 12.1 & 2.38 & 2.98 & & 0.16 & 2.18 & 2.13 & 2.47 & 0.13 \\
\hline Assam & 1.31 & 2.49 & 3.24 & & 0.22 & 4.37 & 2.56 & 3.18 & 0.23 \\
\hline Bihar & 2.11 & 2.92 & 4.53 & & 0.43 & 7.08 & 2.98 & 4.11 & 0.45 \\
\hline Gujarat & 3.01 & 2.38 & 3.02 & & 0.30 & 8.31 & 2.06 & 2.85 & 0.16 \\
\hline Haryana & 1.42 & 2.50 & 3.56 & & 0.35 & 4.24 & 2.33 & 2.86 & 0.22 \\
\hline Himachal Pradesh & 2.45 & 2.03 & 3.08 & & 0.16 & 3.21 & 2.02 & 2.59 & 0.10 \\
\hline Karnataka & 8.42 & 2.18 & 2.83 & & 0.15 & 3.78 & 1.80 & 2.47 & 0.15 \\
\hline Kerala & 2.8 & 2.40 & 2.32 & & 0.11 & 2.8 & 2.18 & 2.11 & 0.11 \\
\hline Madhya Pradesh & 6.12 & 2.67 & 3.56 & & 0.34 & 13.3 & 2.58 & 3.39 & 0.29 \\
\hline Maharashtra & 14.07 & 2.22 & 2.86 & & 0.20 & 5.5 & 2.33 & 2.76 & 0.17 \\
\hline Delhi & 2.37 & 2.30 & 3.18 & & 0.20 & 0.54 & 2.31 & 2.95 & 0.13 \\
\hline Odisha & 2.73 & 2.65 & 3.09 & & 0.32 & 6.22 & 2.37 & 2.79 & 0.25 \\
\hline Punjab & 2.52 & 2.06 & 3.08 & & 0.21 & 4.01 & 2.12 & 2.62 & 0.17 \\
\hline Rajasthan & 3.08 & 3.17 & 4.15 & & 0.40 & 7.68 & 2.59 & 3.52 & 0.29 \\
\hline Tamilnadu & 11.39 & 2.08 & 2.61 & & 0.08 & 6.99 & 2.05 & 2.18 & 0.25 \\
\hline Uttar Pradesh & 19.73 & 2.71 & 4.19 & & 0.35 & 15.65 & 3.03 & 4.03 & 0.44 \\
\hline West Bengal & 4.39 & 2.06 & 2.79 & & 0.16 & 2.87 & 2.29 & 2.69 & 0.14 \\
\hline Telangana^ & & & & & & 1.28 & 2.12 & 2.69 & 0.14 \\
\hline Total & 100 & 2.40 & 3.25 & & 0.23 & 100 & 2.46 & 3.14 & 0.26 \\
\hline
\end{tabular}

Notes: ^ Telangana was part of Andhra Pradesh until 2 June 2014. 
Figure A1: Fertility gap and socio-economic variables (NFHS 3)
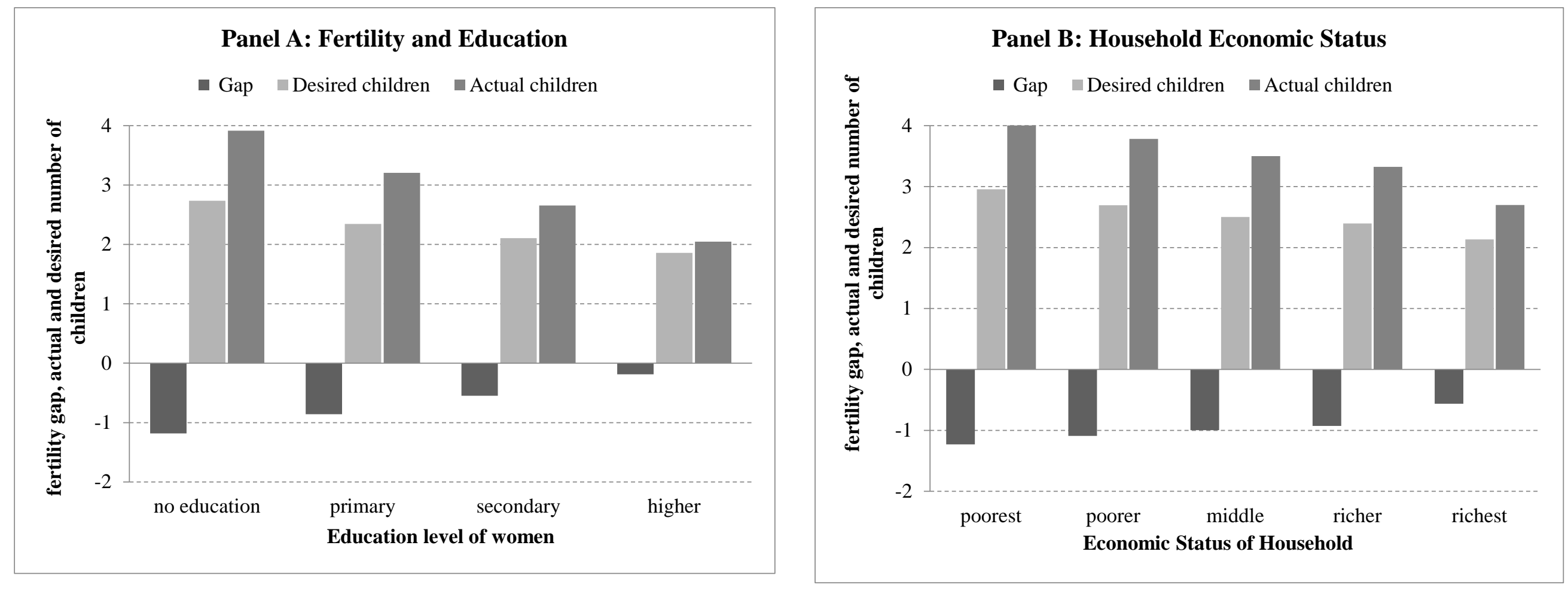

Notes: Fertility gap defined as difference between ideal and actual number of children. Using NFHS 3 and NFHS 4 data. Sample restricted to women aged 40 and above. 